\title{
Modelling the marine eutrophication: A review
}

\author{
Ménesguen Alain ${ }^{1,{ }^{*}}$, Lacroix Geneviève ${ }^{2}$
}

${ }^{1}$ Department of Coastal Environment Dynamics (DYNECO), French Research Institute for the Exploitation of the Sea (IFREMER), Centre de Bretagne, B.P. 70, 29280 Plouzané, France

${ }^{2}$ Royal Belgian Institute of Natural Sciences (RBINS), Operational Directorate Natural Environments (OD Nature), Gulledelle 100, 1200 Brussels, Belgium

* Corresponding author : Alain Ménesguen, email address : alain.menesguen@ifremer.fr

\begin{abstract}
:
In the frame of a national, joint scientific appraisal, 45 scientific French-speaking experts have been mandated in 2015-2016 by the French ministries of Environment and Agriculture to perform a global review of scientific literature dealing with the eutrophication phenomenon, in freshwater as well as in marine waters. This paper summarizes the main results of this review restricted to a sub-domain, the modelling approach of the marine eutrophication. After recalling the different aims pursued, an overview is given on the historical time course of this modelling effort, its world distribution and the various tools used. Then, the main results obtained are examined, highlighting the specific strengths and weaknesses of the present models. Needs for future improvement are then listed.
\end{abstract}

\section{Graphical abstract}

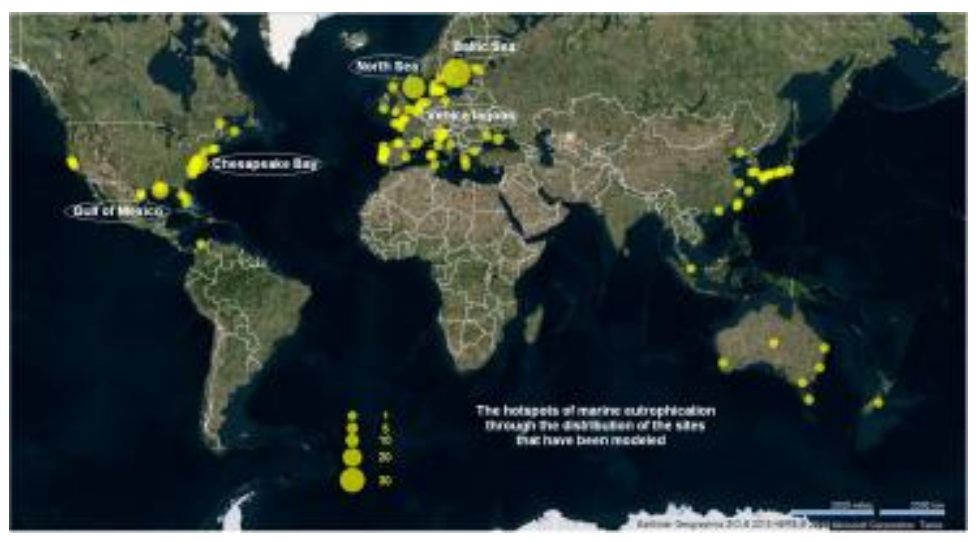




\section{Highlights}

- 291 references on marine eutrophication modelling have been analysed. 4 batches have been done: estuaries, lagoons, coastal seas, "green tides". - The world hotspots of eutrophication are listed, with their main results. The evolution of tools, their strengths and weaknesses are described.

Keywords: Marine eutrophication, Biogeochemical models, Deterministic versus statistical, Nutrient reduction scenarios, Land-sea coupling, Climate change 


\section{Introduction}

At the end of the $20^{\text {th }}$ century, the Oslo and Paris Commission (OSPAR) in charge of promoting the good ecological status of West-European coastal seas proposed an operational definition of marine eutrophication (OSPAR, 1997). Eutrophication was then considered as "the result of excessive enrichment of water with nutrients which may cause an increase in the accelerated growth of algae in the water column and higher forms of plants living on the bottom of the sea." The OSPAR definition pointed out that eutrophication "may result in a range of undesirable disturbances in the marine ecosystem, including a shift in the composition of the flora and fauna which affects habitats and biodiversity, and the depletion of oxygen, causing death of fish and other species." The most mediated aspects of the marine eutrophication are the mass accumulation of green macroalgae on beaches (the so-called "green tides") or in lagoons, as well as the intense proliferations of some phytoplanktonic species in coastal seas (the so-called "colored waters"). However, massive kills of fishes and benthic fauna have also revealed the deleterious effects of the invisible anoxia of bottom waters, leading to sporadic or permanent "dead zones" in more and more places (Diaz and Rosenberg, 2008). Eutrophication can be a natural process: in inland waters, ageing of a lake over geological time scales induces a slow accumulation of organic material, whereas in some oceanic areas, as off Namibia (Brüchert et al., 2003), intermittent and sudden massive inputs of deep, nutrient rich water upwelled by wind episodes can trigger a high surface production of phytoplankton, which sinks and feeds bottom anaerobic sulphate reducing bacteria. To embrace accumulation of allochtonous organic matter as well as sedimentation of locally produced algal material, Nixon (2009) defined eutrophication as an "increase in supply of organic matter". Most of present cases of marine eutrophication are from anthropogenic origin, i.e. caused by recent abnormal man-made inputs of nutrients or organic wastes. The study of many lakes, first affected by anthropogenic eutrophication in the second half of the 
$20^{\text {th }}$ century, has shown (Vollenweider, 1968) that eutrophication is possible only if the surface mixed layer is sufficiently thin and illuminated to allow a primary production greater than the algal respiration and hence, to ensure a rapid algal growth. The biomass produced can accumulate only if the water body exhibits a residence time of several days, i.e. is sufficiently confined. Eutrophication in lakes revealed to have been mainly triggered by massive anthropogenic inputs of inorganic phosphorus (phosphate). In coastal seas however, ecosystems are naturally open, they show strong continuous gradients extending from the estuaries to the offshore waters. Their high salinities are not in favor of an efficient gaseous nitrogen fixation by cyanobacteria, so that the controlling role of nitrogen may override the phosphorus one. A part of the terrestrial loadings of nutrients is exported into the oceanic waters. Gyres of various sizes embedded in the mainstream tidal residual flow provide spatially heterogeneous residence times, whereas oceanic oscillations, such as the North Atlantic Oscillation, can modulate the marine response to nutrient enrichment... This further adds complexity to the marine eutrophication process.

Scientists willing to understand the mechanism of eutrophication as well as public administrations aiming at defining the optimal actions for remediation have used mathematical models to explore hypotheses or remediation scenarios during the four last decades. The need for integrated actions from the watersheds down to the open ocean under a changing climate will probably increase the role of numerical models in tackling the eutrophication problem in the future. What help did the models provide up to now, what cannot they do at this moment, what would we like they should be able to do in the future? This paper tries to answer these questions from the existing literature. 


\section{Methods used to build the inventory}

This work has been conducted in 2015-2016, as part of a global review of scientific literature dealing with eutrophication, in fresh inland waters as well as in marine coastal waters. The French Ministry of Ecological and Social Transition (MTES), together with the French Agency for Biodiversity (AFB) and the French Ministry of Agriculture and Food (MAA) mandated the French National Centre for Scientific Research (CNRS), along with three other French public scientific institutes (National Institute for Agronomic ResearchINRA, French Institute for Research and Exploitation of the Sea-IFREMER, and Institute for Scientific Research and Technology for Environment and Agriculture-IRSTEA), to coordinate a panel of 45 scientific French-speaking experts which could cover all the different aspects of the eutrophication problem (biogeochemistry, ecology, links with urban and agricultural practices, sociologic impact and legal treatment). This joint scientific appraisal (a so-called French ESCo "Expertise Scientifique Collective") should help the public authorities to redefine French regulatory texts dealing with the complex and controversial issue of eutrophication, especially the role played by nitrogenous and phosphorous nutrients in this phenomenon. This will better establish the revision of vulnerable zones in respect of the Nitrate Directive (Directive 91/676/EEC) as well as the implementation of the European directives on the management of aquatic environments, i.e. the Water Framework Directive (WFD, Directive 2000/60/EC), the Marine Strategy Framework Directive (MSFD, Directive 2008/56/EC) and the Urban Waste Water Treatment Directive (UWWTD, 91/271/EEC).

The global appraisal is based on approximately 4,000 scientific references. The present subset, dealing only with the modelling of marine eutrophication, is based on 291 references. They result from a first extraction from the Web of Science Core Collection thanks to a bibliographic search equation, followed by the discard of some inappropriate references (e.g. dealing with inland waters) and the addition of some pertinent scientific 
papers known by the authors, but not selected by the search equation. As the work has been split into four distinct domains (estuaries, lagoons, coastal seas, "green tides"), Table 1 gives for each domain the search equation and the number of papers selected by it, along with the numbers of discarded and added papers. The number of published modelling studies per year (Fig.1) reveals that the modelling of marine eutrophication is relatively recent, beginning at the end of the 80 's. Whereas studies on estuaries and coastal areas had shown a regular increase since 1990, studies on "green tides" as well as on lagoons have kept a weak steady state since the mid 90's. These research papers were published in 76 journals, the 5 most cited being Ecological Modelling (15.8\%), Journal of Marine Systems (13.6\%), Estuarine Coastal and Shelf Science (9.7\%), Marine Ecology Progress Series (5.4\%), Hydrobiologia (3.9\%), collectively publishing $49.4 \%$ of all papers.

\section{Aims of the modelling approach}

The first aim of the eutrophication models was to help understanding the eutrophication process and to reproduce its main features, i.e. the intense phytoplanktonic blooms (Chan et al., 2002; Kishi and Ikeda, 1986; Dippner, 1993; Baretta et al., 1994; Fennel, 1995; Tett and Walne, 1995; Yanagi et al., 1995; McEwan et al., 1998; Cugier et al., 2005; Tamvakis et al., 2012) or the mass accumulation of ulvaceae (Ménesguen and Salomon, 1988; Bendoricchio et al., 1994; Coffaro and Sfriso, 1997; Martins and Marques, 2002; Lovato et al., 2013; Coffaro and Bocci, 1997; Brush and Nixon, 2010; Trancoso et al., 2005; SilvaSantos et al., 2006), and the possible hypoxia (or anoxia) induced in the bottom waters (Humborg et al., 2000, Chapelle, 1995; Chapelle et al., 1994; Oguz et al., 2000; Grégoire and Lacroix, 2001; Karim et al., 2002; Tuchkovenko and Lonin, 2003; Grégoire et al., 2008; Grégoire and Soetaert, 2010; Evans and Scavia, 2011; Pena et al., 2010; Wan et al., 2012; Große et al., 2017). Because the dynamics of estuaries is strongly controlled by physical drivers (river flow rate, turbidity, haline stratification), the estuarine models have very often 
been used to assess the respective role of these drivers, especially on the onset of hypoxic conditions (Peterson and Festa, 1984; Cole and Cloern, 1987; Soetaert et al., 1994; Vanderborght et al., 2002; Muylaert et al., 2005; Talke et al., 2009; Nash et al., 2011; Gypens et al., 2013; Gallegos, 2014; O'Boyle et al., 2015; Mathews et al., 2015; Fear et al., 2004; Talke et al., 2009; Robson et al., 2008; Talke et al., 2009; Nash et al., 2011; Arndt et al., 2011; Wang et al., 2013; Liu and de Swart, 2015; O'Boyle et al., 2015; Chen et al., 2014; Chen et al., 2015; Benoit et al., 2006; Bruce et al., 2011; Hipsey et al., 2013; Cho et al., 2015; Miguez et al., 2001).

Beyond these main aspects, the models have been also used to explore the competition between diverse primary producers: diatoms vs dinoflagellates or Prymnesiophyceae (Phaeocystis sp.) as well as diatoms vs cyanobacteria (Petihakis et al., 1999; Guillaud and Ménesguen, 1998; Guillaud et al., 2000; Gypens et al., 2007; van den Berg et al., 1996a; Blauw et al., 2009; Spatharis and Tsirtsis, 2013), Ulva vs phanerogams Zostera and Ruppia (Giusti and Marsili-Libelli, 2005; Cioffi and Gallerano, 2006; Canal-Verges et al., 2014), or macro- vs microalgae (Baird et al., 2003; Madden and Kemp, 1996; Buzzelli et al., 2014; Sohma et al., 2004).

Rapidly, the modelling effort has been applied to assess the respective role of various nutrient sources, mainly the continental watersheds vs the oceanic inputs (Lowery, 1998; Meeuwig et al., 2000; Kauppila et al., 2003; Arismendez et al., 2009; Plus et al., 2006; Malhadas et al., 2014; Timmermann et al., 2010; Beck et al., 2001; Roelke et al., 1999), or the upward flux from sediments (Fernandez et al., 2012; van Raaphorst et al., 1988; Magalhaes et al., 2008; Liu et al., 2009; Bruce et al., 2011a). The inputs of nitrogen from the atmosphere have been recently taken into account in the Baltic Sea (Ruoho-Airola et al., 2012), the North Sea (Troost et al., 2013; Djambazov and Pericleous, 2015; Dulière et al., 2017), and in Singapore region (Sundarambal et al., 2010); they can reach up to $29 \%$ of the nitrogen inputs 
in Belgian offshore waters (Dulière et al., 2017), but they remain in most cases of minor importance in the case of strong coastal eutrophication. Since the 2000's, the use of numerical tracers has become more and more popular to track the fate of various nutrient loadings, either considered as simple passive and conservative dyes (Kasih and Kitada, 2004; Lacroix et al., 2007; Wild-Allen et al., 2010; Eilola et al., 2014; Djambazov and Pericleous, 2015) or as active and form-changing variables (Ménesguen et al., 2006; Sugimoto et al., 2010; Timmermann et al., 2010; Troost et al., 2013; Los et al., 2014; Dulière et al., 2017; Große et al., 2017). Forcing models with time-series of past loadings and meteorology has allowed reconstruction of the decadal change of the eutrophication status of large areas, such as the North Sea (Pätsch and Radach, 1997; de Vries et al., 1998; Lancelot et al., 2009), the Gulf of Mexico (Justic et al., 2002; Justic et al., 2003; Scavia et al., 2003; Justic et al., 2007; Evans and Scavia, 2011; Obenour et al., 2015; Feist et al., 2016), the Baltic Sea (Neumann and Schernewski, 2008). As one of the recurrent questions asked by the decision-makers is about the limiting factor of the excessive algal production, several studies have been focused on that question: (Gallegos and Jordan, 1997; Fan and Song, 2014; Liu et al., 2014; O'Boyle et al., 2015; Lin et al., 2008; Ménesguen and Salomon, 1988; Ménesguen, 1992). However, the commonest use of the models is the simulation of scenarios for operational recommendations. Particularly in the case of strongly modified ecosystems, far from their natural status and from the domain of linear response to nutrient loadings, models are the only way to forecast the effects of various scenarios of loading reduction. The current situation of loadings is taken as the $100 \%$ reference, and reductions $(<100 \%)$ or augmentations $(>100 \%)$ can be tested (Olufeagba and Flake, 1981; Lonin and Tuchkovenko, 2001; Onandia et al., 2015; Lung, 1988; Lung and Testerman, 1989; Meeuwig, 1999; Lung and Nice, 2007; Camacho et al., 2015; Garcia et al., 2002; Sohma et al., 2008; Lenhart et al., 2010; Lacroix et al., 2007; Hipsey et al., 2013; Skerratt et al., 2013; Liu and Chan, 2014; del Barrio et al., 2014; 
Timmermann et al., 2014; Steward and Lowe, 2010; Saraiva et al., 2007; Gypens et al., 2013; Murray and Parslow, 1999; Cugier et al., 2005; Cerco and Noel, 2013; Qiao et al., 2014; Los et al., 2014; Justic et al., 2007; Scavia and Donnelly, 2007; Liu and Scavia, 2010; Testa et al., 2014). More recently, models have been used to assess the ecological status of the natural ecosystems without any anthropogenic impact, the so-called "pristine" situation (Lancelot et al., 2009; Lancelot et al., 2014). Simulations with current nutrient loadings, reduced ones, or even pristine ones have been compared, especially in the case of wide coastal areas, to the requirements of the so-called Good Ecological Status (GES), in compliance with the European Commission Directives (WFD and MSFD) or the OSPAR and HELCOM requirements (Nobre et al., 2005; Allen et al., 2008; Troost et al., 2014). Up to now, very few attempts have been made to invert the cause-effect relationship linking nutrient loadings and marine eutrophication status, in order to be able to compute directly the reductions of loadings necessary to ensure a fixed level of marine ecological status (Borsuk et al., 2001a; Borsuk et al., 2004). Recently, this question has been treated thanks to the Simplex optimization technique, provided the cause-effect relationship is not too far from linearity. This allows computing the most cost-effective terrestrial load reductions which could lead to the GES (Los et al., 2014, Ménesguen et al., 2018). In some cases, models have also been used to explain the lack of severe eutrophication in coastal areas heavily enriched by the tributaries (LePape and Ménesguen, 1997; Powley et al., 2014; Machado and Imberger, 2014).

Especially in lagoons, some models have been used to assess the benefit which could be expected from various remediation techniques: deriving tributaries from the lagoon into the coastal sea (Ren et al., 2014), harvesting the algae (Cioffi and Gallerano, 2001; Allegretto and Papini, 2008), increasing the water turn-over (Cioffi et al., 1995; Lonin and Tuchkovenko, 2001; Onandia et al., 2015), reducing the oyster biomass under cultivation (Chapelle et al., 2001), or removing the organic-rich surficial layer of the sediment (Cioffi and Gallerano, 
2001). The impact of eutrophication on shellfish or fish farming has been explored (Bacher et al., 1997; Grangeré et al., 2010; Timmermann et al., 2014), as well as the inverse link, i.e. the possible use of cultivated herbivorous to limit the phytoplankton proliferation (Fulford et al., 2007; Cerco et al., 2010). This is a very applied form of the more general question about the modifications of the entire foodweb by the eutrophication process (Doi and Nitta, 1991; Lancelot et al., 2002; Barausse et al., 2009; Townsend, 2014; Luang et al., 2014). Very few models have investigated the possible interactions of eutrophication and toxic pollutants (Legovic, 1997; Driscoll et al., 2012).

Up to now, the economic impact of the marine eutrophication remains rarely modelled (Cellina et al., 2003; Shepherd et al., 2007; Lancelot et al., 2011; Laukkanen et al., 2009; Ahlvik et al., 2014; Timmermann et al., 2014). The probable impact of climate change on the marine eutrophication is a growing issue (Martins et al., 2008; Eilola et al., 2012 ; Meier et al., 2011; Meier et al., 2012; Skogen et al., 2014; Bring et al., 2015; Lessin et al., 2014; Lopes et al., 2015; Ryabchenko et al., 2016; Picart et al., 2015). However, turning the results of models into a quantitative, distributed risk index which can be mapped geographically remains unfamiliar for eutrophication modellers (Druon et al., 2004; Cosme et al., 2015).

\section{Target sites and periods covered by the models}

The global geographic distribution of the published models of marine eutrophication is given in Fig. 2. Historically speaking, the modelling effort has pointed out the hotspots of marine eutrophication.

Among the coastal areas threatened by eutrophication, the top five which have given rise to the biggest modelling efforts are: 
1/ the Baltic Sea (Fennel, 1995, 2010; Carlsson et al., 1999; Helminen et al., 1998; Neumann et al., 2002; Berger et al., 2004; Neumann and Schernewski, 2005 ; Savchuk and Volkova, 1990; Savchuk and Wulff, 1999; Korpinen et al., 2004; Savchuk and Wulff, 2007; Neumann and Schernewski, 2008; Savchuk and Wulff, 2009; Laukkanen et al., 2009; Eilola et al., 2009; Eilola et al., 2011; Yekta and Rahm, 2011; Meier et al., 2011; Meier et al., 2012; Wan et al., 2012; Eilola et al., 2012; Bergstrom et al., 2013; Ahlvik et al., 2014; Eilola et al., 2014; Lehmann et al., 2014; Lessin et al., 2014; Dimberg and Bryhn, 2014; Almroth-Rosell et al., 2015; Janssen et al., 2015; Ryabchenko et al., 2016; Almroth and Skogen, 2010; Skogen et al., 2014; Edelvang et al., 2005; Bring et al., 2015)

2/ the North Sea (Baretta et al., 1994; Slomp et al., 1996; van den Berg et al., 1996a; van den Berg et al., 1996b; Baretta-Bekker et al., 1997; Pätsch and Radach, 1997; Tett and Walne, 1995; de Vries et al., 1998; Druon et al., 2004; Lancelot et al., 2004; Lancelot et al., 2005; Lancelot et al., 2007; Gypens et al., 2007; Lacroix et al., 2007; Allen et al., 2008; Gypens et al., 2009; Lancelot et al., 2009; Blauw et al., 2009; Lenhart et al., 2010; Lancelot et al., 2011; Troost et al., 2013; Passy et al., 2013; Troost et al., 2014); Los et al., 2014; Lancelot et al., 2014; Picart et al., 2015; Große et al., 2017)

3/ the Gulf of Mexico (Chen et al., 1997; Justic et al., 2007; Morse and Eldridge, 2007; Hetland and DiMarco, 2008; Evans and Scavia, 2011; Obenour et al., 2015; Feist et al., 2016)

4/ the Chesapeake Bay (Cerco and Cole, 1993; Cerco, 1995; Fulford et al., 2007; Cerco et al., 2010; Liu and Scavia, 2010; Cerco and Noel, 2013; Sturdivant et al., 2013; Muller and Muller, 2015)

5/ the Black Sea (Yakushev and Neretin, 1997; Legovic, 1997; Oguz et al., 2000; Grégoire and Lacroix, 2001; Lancelot et al., 2002; Grégoire et al., 2008; Grégoire and Soetaert, 2010). 
In their review of hypoxia models, (Pena et al., 2010) add to these five big sites three others, the Tokyo Bay, the Gulf of St. Lawrence and the Cariaco Basin in the north of Venezuela. A lot of smaller sites have also been modelled, from France (Pénard et al., 2007; Chapelle et al., 1994; Guillaud and Ménesguen, 1998; Guillaud et al., 2000; Cugier et al., 2005; Passy et al., 2016) or Italy (Dippner, 1993; Druon et al., 2004; Barausse et al., 2009) to Japan (Kishi and Ikeda, 1986; Yanagi et al., 1995; Mukai et al., 1985; Doi and Nitta, 1991; Karim et al., 2003a; Karim et al., 2003b; Karim et al., 2002; Kasih and Kitada, 2004; Sohma et al., 2004; Sugimoto et al., 2010; Koriyama et al., 2011), China (Chau, 2007; Qiao et al., 2014; Li et al., 2008) or Australia (Murray and Parslow, 1999; McEwan et al., 1998; Machado and Imberger, 2014; Wild-Allen et al., 2010).

Regarding the green macroalgae, the first model appeared in Brittany (France) at the end of the 80's (Ménesguen and Salomon, 1988), followed by improved versions up to now (Ménesguen, 1992; Ménesguen et al., 2006; Perrot et al., 2014). The biggest "green tide" in the world at the end of the $20^{\text {th }}$ century, the Venice lagoon, has been modelled mainly at the end of the 90's (Solidoro et al., 1995; Solidoro et al., 1997b; Coffaro and Sfriso, 1997; Coffaro and Bocci, 1997; Bergamasco and Zago, 1999; Lovato et al., 2013), whereas the Sacca di Goro lagoon, south of the Po delta, waited for the early 2000's (Cellina et al., 2003; Bondavalli, 2003). The present biggest «green tide», native from the seaweed farms of the Shandong coast and drifting in the Yellow Sea up to Qingdao beaches, begun to be modelled very recently (Zhang et al., 2015). Besides these main sites, much smaller "green tides" have been studied in Portugal (Martins et al., 1997; Martins and Marques, 2002; Silva-Santos et al., 2006; Martins et al., 2008; Trancoso et al., 2005), in Denmark (Nielsen, 1997; Canal-Verges et al., 2014), and in the U.S.A (Brush and Nixon, 2010).

In addition to the cases of green macroalgae proliferation previously reported, several Mediterranean lagoons have been modelled for their hypoxic episodes or their excessive 
phytoplanktonic blooms: the French Thau lagoon (Chapelle, 1995; Bacher et al., 1997; Chapelle et al., 2000; Chapelle et al., 2001; Plus et al., 2003; Plus et al., 2006), the Italian lagoons of Venice (Dejak et al., 1987), Orbetello (Cioffi et al., 1995; Giusti and MarsiliLibelli, 2005; Rubegni et al., 2013), Fogliano (Cioffi and Gallerano, 2001; Hull et al., 2008), Tortoli (Cioffi and Gallerano, 2006) and Cabras (Padedda et al., 2010), the Spanish lagoon of Albufera de Valencia (Fernandez et al., 2012; Onandia et al., 2015), and the Greek ones of Vistonis (Gikas et al., 2009), Gialova (Petihakis et al., 1999), Aitoliko-Messolonghi (Gianni and Zacharias, 2012). Few lagoons have been modelled along the Atlantic coasts: the Spanish Victoria lagoon in the Bay of Biscay (Zouiten et al., 2013), the Portuguese lagoons Obidos (Malhadas et al., 2014) and Ria de Aveiro (Lopes et al., 2015), the Columbian Ciénaga de Tesca lagoon (Lonin and Tuchkovenko, 2001), and the USA lagoons located in Texas: San Antonio Bay and Copano Bay (Turner et al., 2014) or in the New-York Bight (Olufeagba and Flake, 1981).

More often than all the other coastal ecosystems, estuaries have been modelled by groups and compared: 6 in the U.S.A (Cole and Cloern, 1987), 10 in the Gulf of Mexico (Lowery, 1998), 12 in Florida (Steward and Lowe, 2010), 15 on the Canadian Prince Edwards island (Meeuwig, 1999), 34 in the world (Borsuk et al., 2001a), 19 Finnish estuaries around the Baltic Sea (Meeuwig et al., 2000; Kauppila et al., 2003), 9 in Portugal (Saraiva et al., 2007), 90 in Ireland (O'Boyle et al., 2015). Some big estuaries have concentrated a lot of studies: the Chesapeake Bay (Lung, 1988; Lung and Testerman, 1989; Madden and Kemp, 1996; Shen, 2006; Lung and Nice, 2007; Adamack et al., 2012; Gallegos and Jordan, 1997; Gallegos, 2014), the Neuse river in North Carolina (Lung, 1988; Borsuk et al., 2002; Borsuk et al., 2001b; Borsuk et al., 2004; Fear et al., 2004; Millie et al., 2006), the Saint Lawrence estuary (Benoit et al., 2006; Katsev et al., 2007), the Yang-Tsé-Kiang estuary (Wang et al., 2013; Chen et al., 2014; Fan and Song, 2014; Liu et al., 2014; Chen et al., 2015), the Belgian 
Scheldt estuary (Soetaert et al., 1994; Vanderborght et al., 2002; Muylaert et al., 2005; Arndt et al., 2011; Gypens et al., 2013), the Portuguese Mondego estuary (Patricio and Marques, 2006; Magalhaes et al., 2008; Baeta et al., 2011) and Tagus estuary (Alvera-Azcarate et al., 2003).

The duration of the simulations covers a few months to a year in the oldest studies, whereas more and more studies since the 2000's deal with 10-years simulations (Plus et al., 2006) or more (Humborg et al., 2000; Lancelot et al., 2007; Blauw et al., 2009; Große et al., 2017).

\section{Modelling tools}

\section{- Deterministic versus statistical models}

Quantitative descriptors of eutrophication status can be computed thanks to either statistical models using measurements of causative variables as inputs and empirically calibrated on some data set, or deterministic models, based on a mathematical theory of the eutrophication process, expressed in a set of differential equations needing some physical/biogeochemical parameters. If the statistical approach was favored before 2000 (Cole and Cloern, 1987; Gowen et al., 1992; Lowery, 1998) owing to its modest computation requirements, the deterministic approach has become the main one since the 90 's, thanks to the tremendous increase of computing power and accessibility. However, the statistical approach has never been abandoned, especially in the U.S.A, and the increase of data availability may have even caused a renewed interest, either within the classical multiregressive frame or within a Bayesian approach producing probability distributions of expected final descriptors under various scenarios, thereby providing some estimate of the uncertainty. Multiregressive models have been used by (Carlsson et al., 1999; Meeuwig, 1999; Meeuwig et al., 2000; Justic et al., 2002; Scavia et al., 2003; Kauppila et al., 2003; 
Turner et al., 2005; Silva-Santos et al., 2006; Muylaert et al., 2005; Millie et al., 2006; Hetland and DiMarco, 2008; Melesse et al., 2008; Liu and Scavia, 2010 ; Koriyama et al., 2011; Chang et al., 2012; Tamvakis et al., 2012; Cerco and Noel, 2013; Gallegos, 2014; Chen et al., 2014; Timmermann et al., 2014; Mathews et al., 2015). Bayesian models can be found in (Arhonditsis et al., 2007; Borsuk et al., 2001; Borsuk et al., 2002; Borsuk et al., 2004; Stow and Scavia, 2009; Liu and Scavia, 2010; Obenour et al., 2015). Whereas statistical models provide an estimate of the uncertainty but are bound to the system in which they were empirically developed (even if Bayesian models may be more adaptable), deterministic models may be run under different constraints in other systems, but the uncertainty associated with their results is difficult to assess.

\section{- Spatial frame}

As presented in Fig. 3, the spatial frame of the model can go from none, in the socalled 0D models (Howarth et al., 1999; Kimmerer et al., 1993; Rosenberg et al., 1977) up to a full-3D grid (Solidoro et al., 1997a); favorite intermediate frames are the horizontal 1D grid (for estuaries), vertical 1D grid (for lagoons and enclosed seas), horizontal 2D grid (for coastal shallow waters without strong freshwater influence), vertical 2D grid (for strongly stratified estuarine and river plume systems).

Various shapes of the grid meshes have been used (Fig. 4). On the horizontal dimension, about $68 \%$ of the 2D and 3D models use Cartesian, rectangular meshes, $27 \%$ use orthogonal curvilinear grids, whereas only $5 \%$ use finite triangular elements. On the vertical dimension, the models usually use layers of unequal thickness, in order to better simulate the sub-surface or the near-bottom gradients. In 2DV (Fig. 3) and full-3D models, many models use a relative vertical discretization (with a so-called $\sigma$-coordinate) instead of a horizontally uniform, absolute vertical discretization (with a so-called $\mathrm{z}$-coordinate), as shown in Fig. 5. 


\section{- Biogeochemical/biological components}

Surprisingly, some models of marine eutrophication do not take explicitly into account the nutrients, which are the necessary fuel of excessive biomass production. Several estuarine models are purely physically driven (Peterson and Festa, 1984; Miguez et al., 2001; Li et al., 2003; Fear et al., 2004; Hagy and Murrell, 2007; Steward and Lowe, 2010; Das et al., 2010; Wang et al., 2013; O'Boyle et al., 2015; Beck et al., 2001; Cho et al., 2015; Talke et al., 2009) as well as some coastal zone models (Smith and Hollibaugh, 1989; Legovic, 1997; Helminen et al., 1998; Druon et al., 2004; Pénard et al., 2007; Wan et al., 2012; Chang et al., 2012; Spatharis and Tsirtsis, 2013). "Green tide" models only interested in deleterious effects, i.e. drift and accumulation of free-floating algae (Canal-Verges et al., 2014) or bottom oxygen depletion (Cellina et al., 2003) can limit the biological component of their model to an algal growth rate depending on temperature. A few models of coastal hypoxic zones, especially in the Gulf of Mexico, are still based on the fundamental couple of state variables characteristic of the first models of river water quality, i.e. the Biological Oxygen Demand (BOD) and the Dissolved Oxygen (DO) (Carlsson et al., 1999; Liu and Scavia, 2010; Liu et al., 2010; Evans and Scavia, 2011; Lehmann et al., 2014).

However, the vast majority of deterministic eutrophication models include a more or less comprehensive and detailed description of the potentially limiting nutrients. In the 90s, most models used only DO (eventually BOD) along with four state variables (NPZD) summarizing the biogeochemical cycle of the most limiting nutrient: $\mathrm{N}$ for nutrient, $\mathrm{P}$ for phytoplankton, Z for zooplankton and D for detritus (van Raaphorst et al., 1988; Fennel, 1995; Tett and Walne, 1995; Bergamasco and Zago, 1999). As nitrogen is considered as the first limiting nutrient in marine ecosystems, especially in summer when the risk of anoxia is greater, a lot of models use nitrogen only (Gowen et al., 1992; Bergamasco and Zago, 1999; Trancoso et al., 2005; Solidoro et al., 1995; Coffaro and Bocci, 1997; Bacher et al., 1997; 
Baird et al., 2003; Vanderborght et al., 2002; Plus et al., 2003; Plus et al., 2006; Turner et al., 2014; Giusti and Marsili-Libelli, 2005; Arismendez et al., 2009; Dugdale et al., 2013; del Barrio et al., 2014; Liu and de Swart, 2015; Bruce et al., 2011a; Bruce et al., 2011b; Gowen et al., 1992; Fennel, 1995; Tett and Walne, 1995; Guillaud and Ménesguen, 1998; Edwards et al., 2003; Nobre et al., 2005; Sugimoto et al., 2010; Machado and Imberger, 2014; Oguz et al., 2000; Grégoire and Lacroix, 2001; Sugimoto et al., 2010). More and more models simulate the phosphorus cycle in parallel with the nitrogen one (Ménesguen and Salomon, 1988; Ménesguen, 1992; Bendoricchio et al., 1994; Solidoro et al., 1995; Coffaro and Sfriso, 1997; Perrot et al., 2014; Lovato et al., 2013; Martins and Marques, 2002; Brush and Nixon, 2010; Martins et al., 2008; Dejak et al., 1987; Humborg et al., 2000; Lonin and Tuchkovenko, 2001; Schernewski and Wielgat, 2001; Rasmussen et al., 2009; Gikas et al., 2009; Padedda et al., 2010; Malhadas et al., 2014; Petihakis et al., 1999; Lopes et al., 2015; Chapelle, 1995; Zouiten et al., 2013; Shen, 2006; Robson et al., 2008; Timmermann et al., 2010; Liu et al., 2014; Gallegos and Jordan, 1997; Roelke et al., 1999; Saraiva et al., 2007; Chan et al., 2002; Buzzelli et al., 2014; Nash et al., 2011; Lung and Nice, 2007; Liu et al., 2009; Liu and Chan, 2014; Camacho et al., 2015; Kishi and Ikeda, 1986; Savchuk and Wulff, 1999; Korpinen et al., 2004; Qiao et al., 2014; Edelvang et al., 2005; Neumann and Schernewski, 2005; WildAllen et al., 2010; Bierman et al., 1994; McEwan et al., 1998; Guillaud et al., 2000; Karim et al., 2002; Karim et al., 2003a; Karim et al., 2003b; Tuchkovenko and Lonin, 2003; Chau, 2007; Neumann and Schernewski, 2008; Blauw et al., 2009; Eilola et al., 2012; Meier et al., 2012; Wan et al., 2012; Troost et al., 2013; Troost et al., 2014; Lessin et al., 2014; AlmrothRosell et al., 2015; Janssen et al., 2015). Especially in estuaries, a lot of statistical models also use $\mathrm{N}$ - and $\mathrm{P}$ loadings as causative variables in order to better constrain the systems where there may be a seasonal alternance in $\mathrm{N}$ and $\mathrm{P}$ limitation or a co-limitation of nutrients (Meeuwig, 1999; Meeuwig et al., 2000; Cole and Cloern, 1987; Muylaert et al., 2005; 
Gallegos, 2014; Timmermann et al., 2014; Mathews et al., 2015; Millie et al., 2006; Lowery, 1998; Kauppila et al., 2003; Chen et al., 2014; Tamvakis et al., 2012; Melesse et al., 2008; Muller and Muller, 2015). The silicon cycle is added in the cases where eutrophication is dominated by phytoplankton production, in order to model the dynamics of diatoms or the export/retention of silica (Soetaert et al., 1994; LePape and Ménesguen, 1997; Grangeré et al., 2010; Arndt et al., 2011; Gypens et al., 2013; Baretta et al., 1994; van den Berg et al., 1996a; Baretta-Bekker et al., 1997; Pätsch and Radach, 1997; de Vries et al., 1998; Kasih and Kitada, 2004; Cugier et al., 2005; Li et al., 2008; Lacroix et al., 2007; Lancelot et al., 2005; Lancelot et al., 2007; Lancelot et al., 2009; Savchuk and Wulff, 2009; Lancelot et al., 2011; Lancelot et al., 2014; Gypens et al., 2007; Gypens et al., 2009; Blauw et al., 2009; Passy et al., 2013; Ryabchenko et al., 2016; Passy et al., 2016; Murray and Parslow, 1999; Powley et al., 2014; Chapelle et al., 1994; van den Berg et al., 1996b; Eilola et al., 2009; Murray and Parslow, 1999; Lancelot et al., 2002; Cerco and Cole, 1993; Park et al., 2005; Sohma et al., 2004; Große et al., 2017). In order to allow varying stoichiometric composition of some compartments, some models use carbon units for zooplankton biomass and detrital variables (Maar et al., 2010; Sohma et al., 2008; Magalhaes et al., 2008; Hipsey et al., 2013; Chen et al., 2015; Lin et al., 2008; Blauw et al., 2009; Große et al., 2017). Some simulate explicitly the biological uptake/production of dissolved inorganic carbon (Flindt and Kamp-Nielsen, 1997; Grégoire et al., 2008; Grégoire and Soetaert, 2010; Skerratt et al., 2013; Wild-Allen and Rayner, 2014; Allen et al., 2008; Picart et al., 2015; Feist et al., 2016), but only one (Vanderborght et al., 2002) simulates the complete carbon cycle, including the carbonate/bicarbonate buffer. So, up to now, eutrophication modelling has not been really coupled to the $\mathrm{pH}$ simulation necessary to assess a possible interaction with ocean acidification. 
The biological state variables of almost all these models are bulk variables (e.g. total phytoplankton, or diatoms and dinoflagellates, or pelagic diatoms, epibenthic diatoms and macrophytes (Madden and Kemp, 1996) or pre-determined target species with literaturederived physiological parameters: Phaeocystis (Gypens et al., 2007; Lacroix et al., 2007; Blauw et al., 2009; Lancelot et al., 2014), Ulva (Ménesguen and Salomon, 1988; Ménesguen, 1992; Bendoricchio et al., 1994; Solidoro et al., 1995; Coffaro and Sfriso, 1997; Perrot et al., 2014; Lovato et al., 2013), Enteromorpha (Martins and Marques, 2002; Martins et al., 2008), Ulva and Gracilaria: (Brush and Nixon, 2010). Trying to simulate deterministically the emergence of the "pristine" biodiversity in non-eutrophicated systems and its modification under increasing nutrient enrichment remains uncommon (Coffaro et al., 1997; Nielsen, 1997), perhaps because of the too difficult validation and the too weak improvement of the result reliability relatively to the more classical approaches, including simple multiple regression models (Silva-Santos et al., 2006; Arhonditsis et al., 2007; Justic et al., 2002; Liu and Scavia, 2010; Bergstrom et al., 2013; Carlsson et al., 1999).

As settling of dead organic matter triggers anoxic, reducing conditions in the sediment, which can modulate the nutrient exchanges between the bottom water and the sediment, particularly in confined lagoons or inland seas, some models have included an explicit sedimentary part to the nutrient cycles (Petihakis et al., 1999; Baretta et al., 1994; Cerco and Cole, 1993; Cerco et al., 2010; Benoit et al., 2006), completed with sulfur, iron and manganese biogeochemical cycles (Chapelle et al., 2001; Sohma et al., 2004; Soetaert and Middelburg, 2009; Testa et al., 2014; Slomp et al., 1996; Morse and Eldridge, 2007; Yekta and Rahm, 2011; Katsev et al., 2007; Sohma et al., 2008; Fennel et al., 2009; Skerratt et al., 2013; Yakushev et al., 2007; Testa et al., 2014).

The consumer levels of the ecosystem (herbivorous, carnivorous) are included in models focused on the impact of eutrophication upon aquaculture and fisheries (Sturdivant et 
al., 2013; Fulford et al., 2007; Grégoire et al., 2008; Luang et al., 2014; Fennel, 2010; Doi and

Nitta, 1991). Such studies use the end-to-end modelling approach, often with the EcopathEcosim formulation of the trophic web (Lin et al., 2007; Baeta et al., 2011; Patricio and Marques, 2006; Timmermann et al., 2014; Barausse et al., 2009; Cerco et al., 2010; Townsend, 2014).

\section{Reliability of models: how do models relate to observations?}

The first task of every model is to mimic some observed key-descriptors of the eutrophication process, i.e. to compare reasonably well to measurements made in the past. This is done thanks to the calibration phase, which consists in tuning the parameters and the boundary conditions of the equations of a deterministic model, or computing the least square estimates of the coefficients of a multi-regressive model. In case of deterministic models, automatic calibration procedures (Gauss-Newton steepest descent method, Nelder-Mead nonlinear simplex, genetic algorithm...) have been rarely used for the simple eutrophication boxmodels containing very few state variables (Shen and Kuo, 1996; Shen and Kuo, 1998; Giusti and Marsili-Libelli, 2005; Shen, 2006; Grégoire et al., 2008). They have become unusable in current fine 3D models exhibiting hundreds of state variables. Parameter calibration remains massively a handmade process, by trial and error, and suffers from the fact that the state variables can be unequally constrained by observed data. Whereas remote sensing from satellites now provides extended coverage of some surface state variables (temperature, suspended particulate matter, chlorophyll $a$ ), and some buoys can deliver in real time high frequency measurements of chlorophyll $a$ and dissolved nutrients or oxygen, about half of the state variables of marine eutrophication models remain hidden by lack of regular measurement: detrital forms of $\mathrm{N}, \mathrm{P}$ or $\mathrm{Si}$, adsorbed phosphate...The simplest metrics used to quantify the adequacy between models and observations are based on sums of instantaneous 
discrepancy between the measured and simulated values, performed upon their algebraic value (bias), or their absolute value (gap) or frequently their quadratic value, with subsequent extraction of the square root (distance, called the Root Mean Square Error RMSE). However, more sophisticated metrics are also used, as the Bravais-Pearson or Spearman correlation coefficients, or the Nash-Sutcliffe efficiency (which compares the quadratic error of the model to the variance of the observations). Since 2010, graphical combinations of various metrics (Fig. 6) have been increasingly used: Taylor's diagram showing the Bravais-Pearson correlation coefficient, the RMSE and the ratio between simulated and observed standard deviation (Neumann and Schernewski, 2008; Eilola et al., 2011; Testa et al., 2014; Lessin et al., 2014), target diagram showing the relative bias against with the RMSE (Lopes et al., 2015). When the time course of values is considered as crucial, auto-correlation of the model error time series can be used (Coffaro and Bocci, 1997), because non-persisting bias can be considered as a sign that no crucial process is missing in the model. On the contrary, when the time succession of values does not matter, but only their statistical distribution, (Cerco and Noel, 2013) and (Picart et al., 2015) have compared the cumulative density functions of the observed and simulated values. The ascertainment arises that there is a general decreasing goodness of fit when one looks at state variables ranging from pure physical ones (temperature, salinity, currents) to biological ones located at a high trophic level. Regarding eutrophication, a clear-cut change arises between inorganic nutrients and the first common biological descriptor, i.e. the total chlorophyll (Allen et al., 2008).

Calibration is followed by model validation, for which (Fitzpatrick, 2009) has defined three types: time validation (the model is run on a period different from the calibration one), space validation (the model is run on a site different from the calibration one) and structure validation (the model must fill some consistency constraints, as the mass conservation, or stay inside some plausible interval). Starting from the example of two models of nitrogen loads 
into nine North-American estuaries, which gave the same fit to measurements, but estimated the part of urban waste in these loads respectively to $47 \%$ or $83 \%$, (Giblin and Vallino, 2003) insist on the space validation on very different sites, as well as on the structure validation by constraining the simulated fluxes by isotope tracking measurements. As pointed out by (Allen et al., 2008), the validation process reveals a common feature of eutrophication models (and more generally ecological models), i.e. their inability to reproduce extreme situations (sudden big blooms or acute hypoxia), which are indeed the most harmful for the ecosystem. A trial of a linear transformation of the simulated values (Picart et al., 2015) does not improve the tails of the distributions of the simulated state variables. In that particular case, authors blamed more the biogeochemical part than the hydraulic one in the weakness of the models, as did (Turner et al., 2014) when they showed the crucial improvement brought by introducing a sedimentary compartment, while Los and Blaas (2010) showed in their retrospective of the successive developments of BLOOM/GEM model since the 80 s that discrepancies between model results and data were caused primarily by inadequacies in the model forcing: hydrodynamics, suspended sediment concentrations and river loads.

Some studies add to the calibration/validation phase a sensitivity analysis, in order to detect the parameters either over-influent or without any effect on the simulated results. By re-running the model with different values of each parameter, each parameter of the equations can be characterized by its normalized sensitivity, i.e. the ratio between the relative effect to the relative cause (Chapelle, 1995). The sensitivity to the time resolution of the physical forcing (wind in Chapelle et al., 2001) or the biogeochemical boundary conditions (marine boundary in (Wild-Allen and Rayner, 2014) is done only when high frequency time-series are available, and allow various sub-sampling. It has revealed the definite incapacity of models to reproduce accurately some transient features in case of a too loose forcing. As soon as the model simulates some long-life compartments (such as detrital matter, or sedimentary pools), 
a several years long period of spin-up is necessary, either to forget the unrealistic initial condition or to confirm the stability of the realistic one imposed from observations. Up to now, very few models have performed a long spin-up period before the nominal simulation: 5 years for the EU-MT-MIKE21 model used by (Rasmussen et al., 2009), 10 years for the ERSEM model used by (Petihakis et al., 1999), 97 years for the RCO-SCOBI model of the Baltic Sea used by (Eilola et al., 2009).

\section{The strength of models: enforcing the land-sea continuum and gaining new information}

The first benefit of modelling eutrophication is to disentangle the roles of the main drivers, i.e. the light availability, the confinement and the nutrients. Grazing is generally not considered as a major driver in controlling the course of eutrophication, because the occurrence of high algal biomasses demonstrates the inefficiency of natural grazers; this is especially true in case of mass blooms of free macroalgae, which escape to their usual grazers living on rocky bottoms. But some models have tried to assess the role of grazing at the very beginning of eutrophication process, as well as the efficiency of a man-made harvest of algal biomass (see further discussion about top-down control in the following chapter). Many estuarine models have pointed out the protective role of high turbidity (Cole and Cloern, 1987; Soetaert et al., 1994; Muylaert et al., 2005; Gallegos, 2014; Chen et al., 2014; Mathews et al., 2015). Many others have also explicitly quantified the control of eutrophication by the residence time, either by applying the Vollenweider's formula (Steward and Lowe, 2010), or by comparing various cases (Peterson and Festa, 1984; Liu and de Swart, 2015; Lung, 1988; Wang et al., 2013; Nash et al., 2011; O'Boyle et al., 2015; Saraiva et al., 2007; Camacho et al., 2015). Some estuarine models (Lin et al., 2008; Buzzelli et al., 2014) show that decreasing the nutrient fluxes by lowering the flow rate may have a worsening effect (increase of residence time and decrease of turbidity, hence increase of phytoplankton biomass). However, 
Chan et al., (2002) showed that the historical decrease of flow rate caused by building impoundments along the Swan River had a negligible effect on the onset of eutrophication compared to the concomitant increase of the nutrient concentrations in the river. Modelling in parallel the nitrogen and phosphorus cycles, and taking into account their main sources (rivers, ocean, sedimentary stocks, atmospheric depositions in some cases) has very often confirmed the prominent role of increased nitrogen inputs in triggering and controlling the marine eutrophication process. The case is quite clear in mass proliferations of green algae in Brittany (Ménesguen and Salomon, 1988; Ménesguen, 1992; Perrot et al., 2014; Ménesguen et al., 2006) or in the Venice lagoon (Bendoricchio et al., 1994; Coffaro and Sfriso, 1997; Bergamasco and Zago, 1999; Giusti and Marsili-Libelli, 2005). In the coastal seas, the biggest anoxic sites apart from the Baltic Sea are also nitrogen-controlled: Justic et al. (2002), Scavia et al. (2003), Evans and Scavia (2011), Obenour et al. (2015), Feist et al. (2016) show the clear link between increasing $\mathrm{N}$ loadings and increasing anoxic area in the Gulf of Mexico. Cerco and Noel (2013), Testa et al. (2014), Stow and Scavia (2009), Liu and Scavia (2010), Liu et al. (2011) have also shown that in the most saline parts of the Chesapeake Bay, the summer blooms leading to bottom anoxia are controlled by the nitrogen inputs. The degradation of the Chesapeake Bay began two centuries ago, and was enhanced when the topdown control provided by natural huge oyster populations collapsed due to overfishing at the end of the $19^{\text {th }}$ century. Eutrophication models containing filter-feeder state variables provide a unique opportunity to compare the efficiency of bottom-up regulations (e.g. decrease of river nutrient loads) with top-down regulations (e.g. massive re-introduction of oyster farming, where the water quality allows). Fulford et al. (2007) show that even the huge pristine stock of oysters could not prevent the central channel from excessive primary production and hence, from bottom anoxia, in the present enriched context. For the English Channel and the North Sea also, the models have pointed out the nitrogen triggering of 
eutrophication phenomena, e.g. the mucus production by the proliferating colonial flagellate Phaeocystis globosa (de Vries et al., 1998; Lancelot et al., 2005; Lenhart et al., 2010; Lancelot et al., 2014), but also the current culmination of diatom blooms by the appearing lack of phosphorus or silicon, along with the increase of dinoflagellate blooms (Guillaud and Ménesguen, 1998; Guillaud et al., 2000; Cugier et al., 2005; Passy et al., 2016) . The current intensity of summer blooms in the downstream part of many estuaries also appears to be Ncontrolled (O'Boyle et al., 2015; Gallegos and Jordan, 1997; Timmermann et al., 2010), but some estuaries remain P-controlled, as freshwater systems (Fan and Song, 2014; Liu et al., 2014; Meeuwig et al., 2000; Lung, 1988; Lung and Testerman, 1989). Lagoons also are very sensitive to nitrogen increase (Baird et al., 2003), but the recurrent sedimentation of organic matter in these calm and shallow water bodies (accelerated by the shellfish cultures (Chapelle et al., 2001)) creates a large benthic stock of $\mathrm{N}$ and $\mathrm{P}$, from which anoxic crises can release sudden bursts of phosphate into the water column (Humborg et al., 2000; Gikas et al., 2009; Schernewski and Wielgat, 2001). The most noticeable exception to the control of marine eutrophication by nitrogen inputs is the Baltic Sea, the northern and eastern parts of it being brackish, with very low salinities in some parts (Bothnian Sea), favorable to cyanobacteria blooms. Savchuk and Wulff (2007), Savchuk and Wulff (2009) and Eilola et al. (2009) have simulated the historic spreading of bottom anoxia caused by the increased loads of phosphorus, and deduced from various forecasts that restoration of a good bottom oxygenation could take around a century even in case of drastic nutrient loads reductions.

The power of models lies in their inexpensive capacity to simulate rapidly alternative scenarios to the present one, or not sampled past situations. Most of the models show that a strong abatement of loadings will be necessary to halt eutrophication of sensitive areas, sometimes equal for $\mathrm{N}$ and $\mathrm{P}$, as in Chinese coastal waters (Qiao et al., 2014), but very often focused on $\mathrm{N}$ loadings now, because the phosphorus ones have been drastically reduced in 
many developed countries. For the Gulf of Mexico, Justic et al. (2007) took into account the observed climatic changes and were compelled to revisit their former recommendations (Justic et al., 2003), and to upgrade from $30 \%$ to $40-45 \%$ the $\mathrm{N}$ load reduction necessary to achieve the containment of the hypoxic area under $5000 \mathrm{~km}^{2}$, as required by the Gulf Hypoxia 2008 Action Plan, designed for reducing, mitigating, and controlling hypoxia in the Northern Gulf of Mexico and improving water quality in the Mississippi River basin. More recently, Liu et al. (2010) and Feist et al. (2016) have pushed this recommendation up to 70\%. In the Chesapeake Bay also, Stow and Scavia (2009), Liu and Scavia (2010) and Liu et al. (2011) have predicted that the $35 \%$ reduction planned for the $\mathrm{N}$ loads will not be enough to keep the anoxic volume under $3 \mathrm{~km}^{3}$. Models offer also an easy way to test simulated land-use scenarios, leading to various forcing by nutrient leakage from continental watersheds. Probably because of the limited area of the watersheds of their tributaries, only two lagoon models have been connected to a watershed model, e.g. SWAT (Plus et al., 2006; Malhadas et al., 2014). Estuarine models are more frequently coupled to a watershed model (Carmichael et al., 2004; Kauppila et al., 2003; Adamack et al., 2012; Meeuwig, 1999; Gypens et al., 2013). Only models of wide coastal zones have increasingly be forced by the outputs of watershed models, used to simulate various scenarios of land use (Lowery, 1998; Cerco and Noel, 2013; Townsend, 2014; Cugier et al., 2005; Lancelot et al., 2005; Lancelot et al., 2009; Lancelot et al., 2011; Lancelot et al., 2014; Gypens et al., 2009; Passy et al., 2013; Ahlvik et al., 2014; Lancelot et al., 2011; Desmit et al., in revision). As previously shown in the Gulf of Mexico or in the Baltic Sea, Lancelot et al. (2011) and Passy et al. (2016) have shown that in the North Sea, only a scenario of drastic reduction of $\mathrm{N}$ river loads, requiring a strong diminution of rearing and fertilization, could restore the coastal water quality in terms of reducing chlorophyll a blooms, though with a limited effect on increasing bottom oxygen (Skogen and Mathisen, 2009). 
If models have been intensively used to encompass the spatial continuum from watersheds to coastal seas, they have also been used since the beginning (Doi and Nitta, 1991) to explore the trophic continuum, from inorganic nutrients up to top predators. Nobre et al. (2005), Barausse et al. (2009), Luang et al. (2014) show that moderate eutrophication does not reduce the secondary production, but shortens the pathways and transform a reticulated trophic web into a few short trophic chains, with an increased transfer of organic matter from the pelagic system to the benthos. Lancelot et al. (2009) have shown also that any decrease in the trophic efficiency (secondary to primary production ratio) related to Phaeocystis dominance was the result of an imbalance between DIN and DIP inputs, explained by the reduction in DIP loads after 1985 while DIN remained elevated.

The pervasive constraint to compare their simulated state variables to measured quantities has probably bridled the creativity of modellers. Using validated models to do "better" than, or to go beyond the observations is a recent practice to be encouraged. Models are indeed the only way to accede to unmeasurable descriptors, e.g. the fraction of a chemical element coming from a specific source, and the age of this element, i.e. the mean time elapsed between the release from the source and the arrival in the current marine position. Initially limited to the use of passive tracers put in the rivers and the oceanic boundary (Kasih and Kitada, 2004; Lacroix et al., 2007; Wild-Allen et al., 2010; Eilola et al., 2014; Djambazov and Pericleous, 2015), this approach has recently moved towards the use of active and formchanging variables, e.g. nitrogen passing from dissolved inorganic form to particulate phytoplankton form, then to zooplankton or detrital forms (Ménesguen et al., 2006; Sugimoto et al., 2010; Timmermann et al., 2010; Troost et al., 2013; Los et al., 2014; Dulière et al., 2017; Große et al., 2017). This technique has the advantage of being non-disruptive of the computed biogeochemical fluxes, whereas the straightforward removal of a nutrient source modifies the balance between the fluxes. Another specific capability of models is the 
automatic computation of an optimal solution of remediation, according to a given target. As optimization techniques are based on a cost function to be minimized, the models can provide a unique opportunity to merge in a unique mathematical cost function biogeochemical and economical objectives, for instance for the Baltic Sea (Laukkanen et al., 2009; Ahlvik et al., 2014) or for the Swedish Limfjord and its mussel farms (Timmermann et al., 2014).

\section{The weakness of simulation: what is not yet modelled? challenges and gaps}

The early deterministic models, running on slow computers with tiny memory, described the biogeochemical cycles with very few bulk variables: if they were easy to understand and to manipulate, they were considered as having a definitely limited reliability and accuracy. The drastic increase of computer power brought the hope that highly more detailed models (structurally refined and spatially resolved) would automatically improve the reliability of the eutrophication models. The development and the successive improvements of the European ERSEM model is a good example of this trend (Baretta et al., 1994; BarettaBekker et al., 1997; Pätsch and Radach, 1997). Surprisingly however, Cerco and Noel (2013), comparing with themselves twenty years before (Cerco and Cole, 1993), note that the huge complexification of the model of the Chesapeake Bay has more succeeded in lightening some dark regions of the model by new state variables than in improving substantially the goodness of fit of the basic descriptors! This frustrating apparent limit to the accuracy of deterministic models has regularly pushed some authors to prefer purely empirical models, either statistical (Gowen et al., 1992; Edwards et al., 2003; Tamvakis et al., 2012) or, more recently, based on neural networks (Melesse et al., 2008; Muller and Muller, 2015). The lack of internal processes however limits the application of these models to scenarios or sites not very different from the case study where the calibration has been done, and prevents them to forecast situations where a hidden variable (not explicitly taken as an input of the model) has changed, for instance in the perspective of climate change. 
As almost all the models of marine eutrophication start with the postulate that the eutrophication process is bottom-up controlled (i.e. by physics and supply of inorganic nutrients), very scarce are those which explore the complementary role of the top-down control, even if some state variables are taken into account in the model (zooplankton, gelatinous plankton, benthic filter feeders). Apart from Kolesar (2006), Fennel (2010) and Lancelot et al. (2002), they focus on the cultivated bivalves only (Fulford et al., 2007; Maar et al., 2010; Grangeré et al., 2010; Timmermann et al., 2014). Cellina et al. (2003) searched the optimal strategy for the anthropogenic top-down control of green algae mass proliferations through an intensive mechanical collecting; they found that an intensive collecting at the very beginning of the algal growth was the most cost-effective.

Modelling the possible modifications of current eutrophication under climate change remains very uncertain, for instance because the flow rates of big rivers such as the Mississippi can change from $-30 \%$ to $+40 \%$ depending on the climatic scenario (Justic et al., 2007). In the Baltic Sea, the unknown long-term behavior of the sedimentary stocks of phosphorus appears as a great factor of uncertainty, even if models agree in prognosing an increase in cyanobacteria blooms (Lessin et al., 2014) and in the size of the anoxic bottom area (Meier et al., 2011); Meier et al., 2012; Eilola et al., 2012; Skogen et al., 2014; Ryabchenko et al., 2016) The effect of sea level rise on marine eutrophication has been rarely studied: Martins et al. (2008) think that the green algae will follow the changes in the extent of very shallow areas, but del Barrio et al. (2014) predict a possible regression of submersed phanerogams.

\section{Future needs}

As eutrophication is a nuisance, its remediation has a heavy cost in financial terms, but also in social consequences. Therefore, the decision-makers would like to know where to focus the nutrient load reductions, and what is the level of confidence in the quantitative 
recommendations produced by the eutrophication models. The first question needs a more detailed quantitative theory of eutrophication, i.e. mathematical relationships linking all the controlling factors (light, confinement, nutrients) to the various symptoms of eutrophication (high algal biomass, bottom oxygen depletion, toxins, shift in biodiversity). This could improve the risk mapping initiated by the EUTRISK (Druon et al., 2004), and increase its reliability in the frame of climate change. As already done for winter nutrients, inverting these cause-effect relationships could be a powerful way to compute the river-specific reductions of loadings necessary to ensure a desired level of remediation. For the second question, as explained before, an exhaustive assessment of the uncertainty on the results caused by the uncertainty on parameters or forcing variables is beyond the common power of current computers, because of the duration of the thousands or millions of simulations necessary, especially if combined effects of several parameters are studied. Nevertheless, a few models, belonging to the statistical type as well as to the deterministic type, have already weighted their mean recommendations by confidence intervals, even if those have been incompletely computed, and this empirical approach must become more common.

Up to now, the vast majority of the models have been used in a short-term perspective, so they could not tackle long term changes of the marine ecosystems. The future models should take into account the long term changes in benthic nutriment stocks, as well as the changes in biodiversity possibly induced by an increasing nutrient enrichment and its subsequent decrease. The bulk variables (diatoms, dinoflagellates...) used for algae will probably be replaced by a lot of competing species differing by their ecophysiological parameters, as introduced by Follows et al. (2007) for the simulation of naturally emerging biogeographical communities, or by size- and trait-based variables used in recent generic models of pelagic ecosystems (Andersen et al., 2015). However, not only bottom-up drivers do control the ecosystem shift during the eutrophication process, some top-down controls may 
change (e.g. from copepod- to jellyfish dominated foodwebs) and more complex and adaptive descriptions of the trophic web have to be also introduced in eutrophication models.

As previously mentioned, a lot of modelling studies have concluded, from a pure ecological and biogeochemical point of view, that returning to a GES might require drastic changes in the watershed use. As these changes are not easily accepted by the society, it appears, from an operational point of view, that better estimating the feasibility and the cost of various remediation scenarios by coupling socio-economic models to eutrophication models could help in building successful remediation plans.

\section{Conclusion}

Models of marine eutrophication have appeared about ten years later than the models of lake eutrophication, but their number is still increasing and accompanies the increase of the spots of marine eutrophication, due to the crescent nutrient inputs from rivers, especially nitrogen. This review reveals that deterministic models are strongly dominant over statistical ones, but that they show a very large range in process and space resolution. They have brought many fruitful operational recommendations, by targeting the responsible nutrient sources and assessing the magnitude of necessary load reductions. They must now move from short-term simulations towards secular ones, and better take into account the environmental accumulators of nutrients (sediments in marine models, underground water and soils in continental models). Introducing numerous types of algae and trait-based foodwebs in these long-term models will not only add complexity to models, but probably allow some qualitative jump in the simulation of dynamic properties of the ecosystems. This will bring new perspectives in forecasting the changing biodiversity resulting from the onset of eutrophication, as well as its regression. Coupling with climate change scenarios will then be more fruitful. Models have had always a heavy tribute to field observations: they will obviously take advantage for their forcing and their calibration/validation from the increase of 
high frequency automated sensors. At the end of this review, it appears that designing new sensors for measuring the "hidden" state variables of the models (e.g. detrital forms in water and sediment) would certainly create a qualitative improvement in the calibration of models, and hence their reliability for operational recommendations. 


\section{Literature cited}

Adamack A.T., Rose K.A., Breitburg D.L., Nice A.J., Lung W.S., 2012. Simulating the effect of hypoxia on bay anchovy egg and larval mortality using coupled watershed, water quality, and individual-based predation models. Marine Ecology Progress Series 445, 141-160.

Ahlvik L., Ekholm P., Hyytiainen K., Pitkanen H., 2014. An economic-ecological model to evaluate impacts of nutrient abatement in the Baltic Sea. Environmental Modelling \& Software 55, 164-175.

Allegretto W., Papini D., 2008. Analysis of a lagoon ecological model with anoxic crises and impulsive harvesting. Mathematical and Computer Modelling 47, 675-686.

Allen J., Smyth T., Siddorn J., Holt M., 2008. How well can we forecast high biomass algal bloom events in a eutrophic coastal sea? Harmful Algae 8, 70-76.

Almroth E., Skogen M.D., 2010. A North Sea and Baltic Sea model ensemble eutrophication assessment. Ambio 39, 59-69.

Almroth-Rosell E., Eilola K., Kuznetsov I., Hall P.O.J., Meier H.E.M., 2015. A new approach to model oxygen dependent benthic phosphate fluxes in the Baltic Sea. Journal of Marine Systems 144, 127-141.

Alvera-Azcarate A., Ferreira J.G., Nunes J.P., 2003. Modelling eutrophication in mesotidal and macrotidal estuaries. The role of intertidal seaweeds. Estuarine Coastal and Shelf Science $57,715-724$.

Andersen K.H., Aksnes D.L., Berge T., Fiksen Ø., Visser A., 2015. Modelling emergent trophic strategies in plankton. Journal of Plankton Research, 37, 862-868.

Arhonditsis G.B., Paerl H.W., Valdes-Weaver L.M., Stow C.A., Steinberg L.J., Reckhow K.H., 2007. Application of Bayesian structural equation modeling for examining phytoplankton dynamics in the Neuse River Estuary (North Carolina, USA). Estuarine Coastal and Shelf Science 72, 63-80. 
Arismendez S.S., Kim H.C., Brenner J., Montagna P.A., 2009. Application of watershed analyses and ecosystem modeling to investigate land-water nutrient coupling processes in the Guadalupe Estuary, Texas. Ecological Informatics 4, 243-253.

Arndt S., Lacroix G., Gypens N., Regnier P., Lancelot C., 2011. Nutrient dynamics and phytoplankton development along an estuary-coastal zone continuum: A model study. Journal of Marine Systems 84, 49-66.

Bacher C., Millet B., Vaquer A., 1997. Modelling the impact of cultivated filter-feeders on phytoplanktonic biomass of the Thau lagoon (France). Comptes Rendus de l'Academie des Sciences, Serie Iii-Sciences de la vie-Life Sciences 320, 73-81.

Baeta A., Niquil N., Marques J.C., Patricio J., 2011. Modelling the effects of eutrophication, mitigation measures and an extreme flood event on estuarine benthic food webs. Ecological Modelling 222, 1209-1221.

Baird M.E., Walker S.J., Wallace B.B., Webster I.T., Parslow J.S., 2003. The use of mechanistic descriptions of algal growth and zooplankton grazing in an estuarine eutrophication model. Estuarine Coastal and Shelf Science 56, 685-695.

Barausse A., Duci A., Mazzoldi C., Artioli Y., Palmeri L., 2009. Trophic network model of the Northern Adriatic Sea: Analysis of an exploited and eutrophic ecosystem. Estuarine Coastal and Shelf Science 83, 577-590.

Baretta J.W., Ruardij P., Vested H.J., Baretta-Bekker J.G., 1994. Eutrophication modelling of the North Sea; two different approaches. Ecological Modelling 75, 471-483.

Baretta-Bekker J.G., Baretta J.W., Ebenhoh W., 1997. Microbial dynamics in the marine ecosystem model ERSEM II with decoupled carbon assimilation and nutrient uptake. Journal of Sea Research 38, 195-211.

Beck N.G., Fisher A.T., Bruland K.W., 2001. Modeling water, heat, and oxygen budgets in a tidally dominated estuarine pond. Marine Ecology Progress Series 217, 43-58. 
Bendoricchio G., Coffaro G., Demarchi C., 1994. A trophic model for Ulva rigida in the lagoon of Venice. Ecological Modelling 75, 485-496.

Benoit P., Gratton Y., Mucci A., 2006. Modeling of dissolved oxygen levels in the bottom waters of the lower St. Lawrence estuary: Coupling of benthic and pelagic processes. Marine Chemistry 102, 13-32.

Bergamasco A., Zago C., 1999. Exploring the nitrogen cycle and macroalgae dynamics in the lagoon of Venice using a multibox model. Estuarine Coastal and Shelf Science 48, 155-175.

Berger R., Bergstrom L., Graneli E., Kautsky L., 2004. How does eutrophication affect different life stages of Fucus vesiculosus in the Baltic Sea? a conceptual model. Hydrobiologia 514, 243-248.

Bergstrom U., Sundblad G., Downie A.L., Snickars M., Bostrom C., Lindegarth M., 2013. Evaluating eutrophication management scenarios in the Baltic Sea using species distribution modelling. Journal of Applied Ecology 50, 680-690.

Bierman V., Hinz S., Zhu D., Wiseman W., Rabalais N., Turner, R., 1994. A preliminary mass-balance model of primary productivity and dissolved oxygen in the Mississippi River plume inner Gulf shelf region. Estuaries 17, 886-899.

Blauw A.N., Los H.F., Bokhorst M., Erftemeijer P.L., 2009. GEM: a generic ecological model for estuaries and coastal waters. Hydrobiologia., 618(1), 175-198.

Bondavalli C., 2003. Effect of eutrophication upon radionuclide dynamics in the Sacca di Goro lagoon (Po River Delta, Italy): a combined field, experimental and modeling study. Environmental Pollution 125, 433-446.

Borsuk M.E., Higdon D., Stow C.A., Reckhow K.H., 2001a. A Bayesian hierarchical model to predict benthic oxygen demand from organic matter loading in estuaries and coastal zones. Ecological Modelling 143, 165-181. 
Borsuk M.E., Powers S.P., Peterson C.H., 2002. A survival model of the effects of bottomwater hypoxia on the population density of an estuarine clam (Macoma balthica). Canadian Journal of Fisheries and Aquatic Sciences 59, 1266-1274.

Borsuk M.E., Stow C.A., Luettich R.A., Paerl H.W., Pinckney J.L., 2001b. Modelling oxygen dynamics in an intermittently stratified estuary: Estimation of process rates using field data. Estuarine Coastal and Shelf Science 52, 33-49.

Borsuk M.E., Stow C.A., Reckhow K.H., 2004. A Bayesian network of eutrophication models for synthesis, prediction, and uncertainty analysis. Ecological Modelling 173, 219-239.

Bring A., Rogberg P., Destouni G., 2015. Variability in climate change simulations affects needed long-term riverine nutrient reductions for the Baltic Sea. Ambio 44, S381-S391.

Bruce E.M., Bruce L.C., Cowell P.J., 2011a. Incorporating geomorphic zonation in nutrient models for coastal-estuarine environments: coupling GIS and aquatic ecosystem modeling. 19th International Congress on Modelling and Simulation (Modsim2011), 1867-1873.

Bruce L.C., Cook P.L.M., Hipsey M.R., 2011b. Using a 3D hydrodynamic-biogeochemical model to compare estuarine nitrogen assimilation efficiency under anoxic and oxic conditions. 19th International Congress on Modelling and Simulation (Modsim2011), 3691-3697.

Brüchert V., Jørgensen B.B., Neumann K., Riechmann D., Schlösser M., Schulz H., 2003. Regulation of bacterial sulfate reduction and hydrogen sulfide fluxes in the central Namibian coastal upwelling zone. Geochimica et Cosmochimica Acta, 67, 4505-4518.

Brush M.J., Nixon S.W., 2010. Modeling the role of macroalgae in a shallow sub-estuary of Narragansett Bay, RI (USA). Ecological Modelling 221, 1065-1079.

Buzzelli C., Doering P., Wan Y.S., Sun D.T., 2014. Modeling ecosystem processes with variable freshwater inflow to the Caloosahatchee River Estuary, southwest Florida. II. Nutrient loading, submarine light, and seagrasses. Estuarine Coastal and Shelf Science 151, 272-284. 
Camacho R.A., Martin J.L., Watson B., Paul M.J., Zheng L., Stribling J.B., 2015. Modeling the factors controlling phytoplankton in the St. Louis Bay estuary, Mississippi and evaluating estuarine responses to nutrient load modifications. Journal of Environmental Engineering 141. Canal-Verges P., Potthoff M., Hansen F.T., Holmboe N., Rasmussen E.K., Flindt M.R., 2014. Eelgrass re-establishment in shallow estuaries is affected by drifting macroalgae - Evaluated by agent-based modeling. Ecological Modelling 272, 116-128.

Carlsson L., Persson J., Hakanson L., 1999. A management model to predict seasonal variability in oxygen concentration and oxygen consumption in thermally stratified coastal waters. Ecological Modelling 119, 117-134.

Carmichael R.H., Annett B., Valiela I., 2004. Nitrogen loading to Pleasant Bay, Cape Cod: application of models and stable isotopes to detect incipient nutrient enrichment of estuaries. Marine Pollution Bulletin 48, 137-143.

Cellina F., De Leo G.A., Rizzoli A.E., Viaroli P., Bartoli M., 2003. Economic modelling as a tool to support macroalgal bloom management: a case study (Sacca di Goro, Po river delta). Oceanologica Acta 26, 139-147.

Cerco C.F., 1995. Simulation of long-term trends in Chesapeake bay eutrophication. Journal of Environmental Engineering-Asce 121, 298-310.

Cerco C.F., Cole T., 1993. 3-dimensional eutrophication model of Chesapeake bay. Journal of Environmental Engineering-Asce 119, 1006-1025.

Cerco C.F., Noel M.R., 2013. Twenty-one-year simulation of Chesapeake bay water quality using the CE-QUAL-ICM eutrophication model. Journal of the American Water Resources Association 49, 1119-1133.

Cerco C.F., Tillman D., Hagy J.D., 2010. Coupling and comparing a spatially- and temporally-detailed eutrophication model with an ecosystem network model: An initial application to Chesapeake Bay. Environmental Modelling \& Software 25, 562-572. 
Chan T.U., Hamilton D.P., Robson B.J., 2002. Modelling phytoplankton succession and biomass in a seasonal west Australian estuary, in: Wetzel, R.G. (Ed.), International Association of Theoretical and Applied Limnology, Vol 28, Pt 2, Proceedings, pp. 1086-1088. Chang N.B., Wimberly B., Xuan Z.M., 2012. Identification of spatiotemporal nutrient patterns in a coastal bay via an integrated k-means clustering and gravity model. Journal of Environmental Monitoring 14, 992-1005.

Chapelle A., 1995. A preliminary model of nutrient cycling in sediments of a Mediterranean lagoon. Ecological Modelling 80, 131-147.

Chapelle A., Lazure P., Ménesguen A., 1994. Modeling eutrophication events in a coastal ecosystem - Sensivity analysis. Estuarine Coastal and Shelf Science 39, 529-548.

Chapelle A., Lazure P., Souchu P., 2001. Modelling anoxia in the Thau lagoon (France). Oceanologica Acta 24, S87-S97.

Chapelle A., Ménesguen A., Deslous-Paoli J.M., Souchu P., Mazouni N., Vaquer A., Millet B., 2000. Modelling nitrogen, primary production and oxygen in a Mediterranean lagoon. Impact of oysters farming and inputs from the watershed. Ecological Modelling 127, 161-181. Chau K., 2007. Integrated water quality management in Tolo Harbour, Hong Kong: a case study. Journal of Cleaner Production 15, 1568-1572.

Chen C., Wiesenburg D., Xie L., 1997. Influences of river discharge on biological production in the inner shelf: A coupled biological and physical model of the Louisiana-Texas shelf. Journal of Marine Research 55, 293-320.

Chen J.Y., Ni X.B., Liu M.L., Chen J.F., Mao Z.H., Jin H.Y., Pan D.L., 2014. Monitoring the occurrence of seasonal low-oxygen events off the Changjiang estuary through integration of remote sensing, buoy observations, and modeling. Journal of Geophysical Research-Oceans $119,5311-5322$. 
Chen X.F., Shen Z.Y., Li Y.Y., Yang Y., 2015. Physical controls of hypoxia in waters adjacent to the Yangtze estuary: A numerical modeling study. Marine Pollution Bulletin 97, 349-364.

Cho C.W., Song Y.S., Kim C.K., Kim T.I., Han J.S., Woo S.B., An S., Choi T., 2015. A modeling study on hypoxia formation in the bottom water of the Youngsan River Estuary, Korea. Journal of Coastal Research 31, 920-929.

Cioffi F., Di Eugenio A., Gallerano F., 1995. A new representation of anoxic crises in hypertrophic lagoons. Applied Mathematical Modelling - 19, - 695.

Cioffi F., Gallerano F., 2001. Management strategies for the control of eutrophication processes in Fogliano lagoon (Italy): a long-term analysis using a mathematical model. Applied Mathematical Modelling 25, 385-426.

Cioffi F., Gallerano F., 2006. From rooted to floating vegetal species in lagoons as a consequence of the increases of external nutrient load: An analysis by model of the species selection mechanism. Applied Mathematical Modelling 30, 10-37.

Coffaro G., Bocci M., 1997. Resources competition between Ulva rigida and Zostera marina: a quantitative approach applied to the Lagoon of Venice. Ecological Modelling 102, 81-95.

Coffaro G., Bocci M., Bendoricchio G., 1997. Application of structural dynamic approach to estimate space variability of primary producers in shallow marine water. Ecological Modelling 102, 97-114.

Coffaro G., Sfriso A., 1997. Simulation model of Ulva rigida growth in shallow water of the Lagoon of Venice. Ecological Modelling 102, 55-66.

Cole B.E., Cloern J.E., 1987. An empirical model for estimating phytoplankton productivity in estuaries. Marine Ecology Progress Series 36, 299-305. 
Cosme N., Koski M., Hauschild M.Z., 2015. Exposure factors for marine eutrophication impacts assessment based on a mechanistic biological model. Ecological Modelling 317, 5063.

Cugier P., Billen G., Guillaud J., Garnier J., Ménesguen A., 2005. Modelling the eutrophication of the Seine Bight (France) under historical, present and future riverine nutrient loading. Journal of Hydrology 304, 381-396.

Das A., Justic D., Swenson E., 2010. Modeling estuarine-shelf exchanges in a deltaic estuary: Implications for coastal carbon budgets and hypoxia. Ecological Modelling 221, 978-985.

de Vries I., Duin R.N.M., Peeters J.C.H., Los F.J., Bokhorst M., Laane R., 1998. Patterns and trends in nutrients and phytoplankton in Dutch coastal waters: comparison of time-series analysis, ecological model simulation, and mesocosm experiments. Ices Journal of Marine Science 55, 620-634.

Dejak C., Lalatta L.M., Meregalli L., Pecenik G., 1987. Development of a mathematical eutrophication model of the lagoon of Venice. Ecological Modelling 37, 1-20.

del Barrio P., Ganju N.K., Aretxabaleta A.L., Hayn M., Garcia A., Howarth R.W., 2014. Modeling future scenarios of light attenuation and potential seagrass success in a eutrophic estuary. Estuarine Coastal and Shelf Science 149, 13-23.

Desmit X., Thieu V., Billen G., Campuzano F., Dulière V., Garnier J., Lassaletta L., Ménesguen A., Neves R., Pinto L., Silvestre M., Sobrinho J.L., Lacroix G. (in revision). Reducing marine eutrophication may require a paradigmatic change. Science of the Total Environment.

Diaz R., Rosenberg R., 2008. Spreading dead zones and consequences for marine ecosystems. Science 321, 926-929. 
Dimberg P.H., Bryhn A.C., 2014. Predicted effects from abatement action against eutrophication in two small bays of the Baltic Sea. Environmental Earth Sciences 72, 11911199.

Dippner J.W., 1993. A lagrangian model of phytoplankton growth dynamics for the Northern Adriatic Sea. Continental Shelf Research 13, 331-355.

Djambazov G., Pericleous K., 2015. Modelled atmospheric contribution to nitrogen eutrophication in the English Channel and the southern North Sea. Atmospheric Environment $102,191-199$

Doi T., Nitta A., 1991. Ecological modeling at Osaka bay related to long-term eutrophication. Marine Pollution Bulletin 23, 247-252.

Driscoll C.T., Chen C.Y., Hammerschmidt C.R., Mason R.P., Gilmour C.C., Sunderland E.M., Greenfield B.K., Buckman K.L., Lamborg C.H., 2012. Nutrient supply and mercury dynamics in marine ecosystems: A conceptual model. Environmental Research 119, 118-131. Druon J., Schrimpf W., Dobricic S., Stips A., 2004. Comparative assessment of large-scale marine eutrophication: North Sea area and Adriatic Sea as case studies. Marine Ecology Progress Series 272, 1-23.

Dugdale R.C., Wilkerson F.P., Parker A.E., 2013. A biogeochemical model of phytoplankton productivity in an urban estuary: The importance of ammonium and freshwater flow. Ecological Modelling 263, 291-307.

Dulière V., Gypens N., Lancelot C., Luyten P., Lacroix G., 2017. Origin of nitrogen in the English Channel and Southern Bight of the North Sea ecosystems. Hydrobiologia.

https://doi.org/10.1007/s10750-017-3419-5.

Edelvang K., Kaas H., Erichsen A.C., Alvarez-Berastegui D., Bundgaard K., Jorgensen P.V., 2005. Numerical modelling of phytoplankton biomass in coastal waters. Journal of Marine Systems 57, 13-29. 
Edwards V.R., Tett P., Jones K.J., 2003. Changes in the yield of chlorophyll a from dissolved available inorganic nitrogen after an enrichment event - applications for predicting eutrophication in coastal waters. Continental Shelf Research 23, 1771-1785.

Eilola K., Almroth-Rosell E., Meier H.E.M., 2014. Impact of saltwater inflows on phosphorus cycling and eutrophication in the Baltic Sea: a 3D model study. Tellus Series a-Dynamic Meteorology and Oceanography 66.

Eilola K., Gustafsson B., Kuznetsov I., Meier H., Neumann T., Savchuk O., 2011. Evaluation of biogeochemical cycles in an ensemble of three state-of-the-art numerical models of the Baltic Sea. Journal of Marine Systems 88, 267-284.

Eilola K., Meier H., Almroth E., 2009. On the dynamics of oxygen, phosphorus and cyanobacteria in the Baltic Sea; A model study. Journal of Marine Systems 75, 163-184. Eilola K., Rosell E.A., Dieterich C., Fransner F., Hoglund A., Meier, H.E.M., 2012. Modeling nutrient transports and exchanges of nutrients between shallow regions and the open Baltic Sea in present and future climate. Ambio 41, 586-599.

Evans M.A., Scavia D., 2011. Forecasting hypoxia in the Chesapeake Bay and Gulf of Mexico: model accuracy, precision, and sensitivity to ecosystem change. Environmental Research Letters 6.

Fan W., Song J.B., 2014. A numerical study of the seasonal variations of nutrients in the Changjiang River estuary and its adjacent sea area. Ecological Modelling 291, 69-81. Fear J., Gallo T., Hall N., Loftin J., Paerl H., 2004. Predicting benthic microalgal oxygen and nutrient flux responses to a nutrient reduction management strategy for the eutrophic Neuse River Estuary, North Carolina, USA. Estuarine Coastal and Shelf Science 61, 491-506. Feist T., Pauer J., Melendez W., Lehrter J., DePetro P., Rygwelski K., Ko D., Kreis R., 2016. Modeling the relative importance of nutrient and carbon loads, boundary fluxes, and sediment fluxes on Gulf of Mexico hypoxia. Environmental Science \& Technology 50, 8713-8721. 
Fennel K., Brady D., DiToro D., Fulweiler R., Gardner W., Giblin A., McCarthy M., Rao A., Seitzinger S., Thouvenot-Korppoo M., Tobias C., 2009. Modeling denitrification in aquatic sediments. Biogeochemistry 93, 159-178.

Fennel W., 1995. A model of the yearly cycle of nutrients and plakton in the Baltic Sea. Journal of Marine Systems 6, 313-329.

Fennel W., 2010. A nutrient to fish model for the example of the Baltic Sea. Journal of Marine Systems 81, 184-195.

Fernandez P.D., Gomez A.G., Alba J.G., Diaz C.A., Cortezon J.A.R., 2012. A model for describing the eutrophication in a heavily regulated coastal lagoon. Application to the Albufera of Valencia (Spain). Journal of Environmental Management 112, 340-352.

Fitzpatrick J.J., 2009. Assessing skill of estuarine and coastal eutrophication models for water quality managers. Journal of Marine Systems 76, 195-211.

Flindt M.R., Kamp-Nielsen L., 1997. Modelling of an estuarine eutrophication gradient. Ecological Modelling 102, 143-153.

Follows M.J., Dutkiewicz S., Grant S., Chisholm S.W., 2007. Emergent biogeography of microbial communities in a model ocean. Science $315,1843-1846$.

Fulford R.S., Breitburg D.L., Newell R.I.E., Kemp W.M., Luckenbach M., 2007. Effects of oyster population restoration strategies on phytoplankton biomass in Chesapeake Bay: a flexible modeling approach. Marine Ecology Progress Series 336, 43-61.

Gallegos C.L., 2014. Long-term variations in primary production in a eutrophic sub-estuary. II. Interannual variations and modeling. Marine Ecology Progress Series 502, 69-83.

Gallegos C.L., Jordan T.E., 1997. Seasonal progression of factors limiting phytoplankton pigment biomass in the Rhode River estuary, Maryland (USA). II. Modeling $\mathrm{N}$ versus $\mathrm{P}$ limitation. Marine Ecology Progress Series 161, 199-212. 
Garcia A., Revilla J.A., Medina R., Alvarez C., Juanes J.A., 2002. A model for predicting the temporal evolution of dissolved oxygen concentration in shallow estuaries. Hydrobiologia 475, 205-211.

Gianni A., Zacharias I., 2012. Modeling the hydrodynamic interactions of deep anoxic lagoons with their source basins. Estuarine Coastal and Shelf Science 110, 157-167. Giblin A.E., Vallino J.. 2003. The role of models in addressing coastal eutrophication problems. In: Canham, C. D., J. J. Cole, and W. K. Lauenroth (eds), The role of models in ecosystem science. Princeton University Press, 327-343.

Gikas G.D., Yiannakopoulou T., Tsihrintzis V.A., 2009. Hydrodynamic and nutrient modeling in a Mediterranean coastal lagoon. Journal of Environmental Science and Health Part a-Toxic/Hazardous Substances \& Environmental Engineering 44, 1400-1423.

Giusti E., Marsili-Libelli S., 2005. Modelling the interactions between nutrients and the submersed vegetation in the Orbetello Lagoon. Ecological Modelling 184, 141-161. Gowen R.J., Tett P., Jones K.J., 1992. Predicting marine eutrophication - The yield of chlorophyll from nitrogen in Scottish coastal waters. Marine Ecology Progress Series 85, 153161.

Grangeré K., Lefebvre S., Bacher C., Cugier P., Ménesguen A., 2010. Modelling the spatial heterogeneity of ecological processes in an intertidal estuarine bay: dynamic interactions between bivalves and phytoplankton. Marine Ecology Progress Series 415, 141-158.

Grégoire M., Lacroix G., 2001. Study of the oxygen budget of the Black Sea waters using a 3D coupled hydrodynamical-biogeochemical model. Journal of Marine Systems 31, 175-202. Grégoire M., Raick C., Soetaert K., 2008. Numerical modeling of the central Black Sea ecosystem functioning during the eutrophication phase. Progress in Oceanography 76, 286333. 
Grégoire M., Soetaert K., 2010. Carbon, nitrogen, oxygen and sulfide budgets in the Black Sea: A biogeochemical model of the whole water column coupling the oxic and anoxic parts. Ecological Modelling 221, 2287-2301.

Große F., Kreus M., Lenhart H.J., Pätsch J., Pohlmann T., 2017. A novel modeling approach to quantify the influence of nitrogen inputs on the oxygen dynamics of the North Sea. Frontiers in Marine Science, 4, 383.

Guillaud J.F., Andrieux F., Ménesguen A., 2000. Biogeochemical modelling in the Bay of Seine (France): an improvement by introducing phosphorus in nutrient cycles. Journal of Marine Systems 25, 369-386.

Guillaud J.F., Ménesguen A., 1998. Modelling over twenty years (1976-1995) of the phytoplanktonic production in the Bay of Seine. Oceanologica Acta 21, 887-906.

Gypens N., Borges A.V., Lancelot C., 2009. Effect of eutrophication on air-sea CO2 fluxes in the coastal Southern North Sea: a model study of the past 50 years. Global Change Biology $15,1040-1056$.

Gypens N., Delhez E., Vanhoutte-Brunier A., Burton S., Thieu V., Passy P., Liu Y., Callens J., Rousseau V., Lancelot C., 2013. Modelling phytoplankton succession and nutrient transfer along the Scheldt estuary (Belgium, The Netherlands). Journal of Marine Systems 128, 89105.

Gypens N., Lacroix G., Lancelot C., 2007. Causes of variability in diatom and Phaeocystis blooms in Belgian coastal waters between 1989 and 2003: A model study. Journal of Sea Research 57, 19-35.

Hagy J.D., Murrell M.C., 2007. Susceptibility of a northern Gulf of Mexico estuary to hypoxia: An analysis using box models. Estuarine Coastal and Shelf Science 74, 239-253. 
Helminen H., Juntura E., Koponen J., Laihonen P., Ylinen H., 1998. Assessing of longdistance background nutrient loading to the Archipelago Sea, northern Baltic, with a hydrodynamic model. Environmental Modelling \& Software 13, 511-518.

Hetland R., DiMarco S., 2008. How does the character of oxygen demand control the structure of hypoxia on the Texas-Louisiana continental shelf? Journal of Marine Systems 70, 49-62.

Hipsey M.R., Bruce L.C., Kilminster K., 2013. A 3D hydrodynamic-biogeochemical model for assessing artificial oxygenation in a riverine salt-wedge estuary. 20th International Congress on Modelling and Simulation (Modsim2013), 1770-1776.

Howarth R.W., Chan F., Marino R., 1999. Do top-down and bottom-up controls interact to exclude nitrogen-fixing cyanobacteria from the plankton of estuaries? An exploration with a simulation model. Biogeochemistry 46, 203-231.

Hull V., Parrella L., Falcucci M., 2008. Modelling dissolved oxygen dynamics in coastal lagoons. Ecological Modelling 211, 468-480.

Humborg C., Fennel K., Pastuszak M., Fennel W., 2000. A box model approach for a longterm assessment of estuarine eutrophication, Szczecin Lagoon, southern Baltic. Journal of Marine Systems 25, 387-403.

Janssen H., Schroder T., Zettler M.L., Pollehne F., 2015. Offshore wind farms in the southwestern Baltic Sea: A model study of regional impacts on oxygen conditions. Journal of Sea Research 95, 248-257.

Justic D., Bierman V., Scavia D., Hetland R., 2007. Forecasting Gulf's hypoxia: The next 50 years? Estuaries and Coasts 30, 791-801.

Justic D., Rabalais N., Turner R., 2003. Simulated responses of the Gulf of Mexico hypoxia to variations in climate and anthropogenic nutrient loading. Journal of Marine Systems 42, 115 126. 
Justic D., Rabalais N.N., Turner R.E., 2002. Modeling the impacts of decadal changes in riverine nutrient fluxes on coastal eutrophication near the Mississippi River Delta. Ecological Modelling 152, 33-46.

Karim M.R., Sekine M., Higuchi T., Imai T., Ukita M., 2003a. Simulation of fish behavior and mortality in hypoxic water in an enclosed bay. Ecological Modelling 159, 27-42. Karim M.R., Sekine M., Ukita M., 2002. Simulation of eutrophication and associated occurrence of hypoxic and anoxic condition in a coastal bay in Japan. Marine Pollution Bulletin 45, 280-285.

Karim M.R., Sekine M., Ukita M., 2003b. A model of fish preference and mortality under hypoxic water in the coastal environment. Marine Pollution Bulletin 47, 25-29.

Kasih G.A.A., Kitada T., 2004. Numerical simulation of water quality response to nutrient loading and sediment resuspension in Mikawa Bay, central Japan: quantitative evaluation of the effects of nutrient-reduction measures on algal blooms. Hydrological Processes 18, 30373059.

Katsev S., Chaillou G., Sundby B., Mucci A., 2007. Effects of progressive oxygen depletion on sediment diagenesis and fluxes: A model for the lower St. Lawrence River Estuary. Limnology and Oceanography 52, 2555-2568.

Kauppila P., Meeuwig J.J., Pitkanen H., 2003. Predicting oxygen in small estuaries of the Baltic Sea: a comparative approach. Estuarine Coastal and Shelf Science 57, 1115-1126. Kimmerer W.J., Smith S.V., Hollibaugh J.T., 1993. A simple heuristic model of nutrient cycling in an estuary. Estuarine Coastal and Shelf Science 37, 145-159.

Kishi M., Ikeda S., 1986. Population dynamics of red tide organisms in eutrophicated coastal waters - Numerical experiment of phytoplankton bloom in the East Seto Inland Sea, Japan. Ecological Modelling 31, 145-174. 
Kolesar S.E., 2006. The effects of low dissolved oxygen on predation interactions between Mnemiopsis leidyi ctenophores and larval fish in Chesapeake Bay ecosystem. $\mathrm{PhD}$ thesis. University of. Maryland. 172 pp.

Koriyama M., Seguchi M., Ishitani T., Isnansetyo A., 2011. Analysis of hypoxia in the western interior parts of the Ariake Sea, Japan, using a box model. Environmental Monitoring and Assessment 179, 65-80.

Korpinen P., Kiirikki M., Koponen J., Peltoniemi H., Sarkkula J., 2004. Evaluation and control of eutrophication in Helsinki sea area with the help of a nested 3D-ecohydrodynamic model. Journal of Marine Systems 45, 255-265.

Lacroix G., Ruddick K., Gypens N., Lancelot C., 2007. Modelling the relative impact of rivers (Scheldt/Rhine/Seine) and Western Channel waters on the nutrient and diatoms/Phaeocystis distributions in Belgian waters (Southern North Sea). Continental Shelf Research 27, 1422-1446.

Lancelot C., Gypens N., Billen G., Garnier J., Roubeix V., 2007. Testing an integrated riverocean mathematical tool for linking marine eutrophication to land use: the Phaeocystisdominated Belgian coastal zone (Southern North Sea) over the past 50 years. Journal of Marine Systems 64, 216-228.

Lancelot C., Passy P., Gypens N., 2014. Model assessment of present-day Phaeocystis colony blooms in the Southern Bight of the North Sea (SBNS) by comparison with a reconstructed pristine situation. Harmful Algae 37, 172-182.

Lancelot C., Rousseau V., Gypens N., 2009. Ecologically based indicators for Phaeocystis disturbance in eutrophied Belgian coastal waters (Southern North Sea) based on field observations and ecological modelling. Journal of Sea Research 61, 44-49. Lancelot C., Spitz Y., Gypens N., Ruddick K., Becquevort S., Rousseau V., Lacroix G., Billen G., 2005. Modelling diatom and Phaeocystis blooms and nutrient cycles in the 
Southern Bight of the North Sea: the MIRO model. Marine Ecology Progress Series 289, 6378.

Lancelot C., Staneva J., Gypens N., Institut O., 2004. Modelling the response of coastal ecosystem to nutrient change, Biogeochemical Silicium Cycle: Elemental to Global Scale, pp. $531-556$

Lancelot C., Staneva J., Van Eeckhout D., Beckers J.M., Stanev E., 2002. Modelling the Danube-influenced north-western continental shelf of the Black Sea. II: Ecosystem response to changes in nutrient delivery by the Danube River after its damming in 1972. Estuarine Coastal and Shelf Science 54, 473-499.

Lancelot C., Thieu V., Polard A., Garnier J., Billen G., Hecq W., Gypens N., 2011. Cost assessment and ecological effectiveness of nutrient reduction options for mitigating Phaeocystis colony blooms in the Southern North Sea: An integrated modeling approach. Science of the Total Environment 409, 2179-2191.

Laukkanen M., Ekholm P., Huhtala A., Pitkanen H., Kiirikki M., Rantanen P., Inkala A., 2009. Integrating ecological and economic modeling of eutrophication: toward optimal solutions for a coastal area suffering from sediment release of phosphorus. Ambio 38, 225235.

Legovic T., 1997. Toxicity may affect predictability of eutrophication models in the coastal sea. Ecological Modelling 99, 1-6.

Lehmann A., Hinrichsen H.H., Getzlaff K., Myrberg K., 2014. Quantifying the heterogeneity of hypoxic and anoxic areas in the Baltic Sea by a simplified coupled hydrodynamic-oxygen consumption model approach. Journal of Marine Systems 134, 20-28.

Lenhart H.J., Mills D.K., Baretta-Bekker H., van Leeuwen S.M., van der Molen J., Baretta J.W., Blaas M., Desmit X., Kuhn W., Lacroix G., Los H.J., Ménesguen A., Neves R., Proctor R., Ruardij P., Skogen M.D., Vanhoutte-Brunier A., Villars M.T., Wakelin S.L., 2010. 
Predicting the consequences of nutrient reduction on the eutrophication status of the North Sea. Journal of Marine Systems 81, 148-170.

LePape O., Ménesguen A., 1997. Hydrodynamic prevention of eutrophication in the Bay of Brest (France), a modelling approach. Journal of Marine Systems 12, 171-186.

Lessin G., Raudsepp U., Maljutenko I., Laanemets J., Passenko J., Jaanus A., 2014. Model study on present and future eutrophication and nitrogen fixation in the Gulf of Finland, Baltic Sea. Journal of Marine Systems 129, 76-85.

Li X.Z., Xiao D.N., Jongman R.H., Harms W.B., Bregt A.K., 2003. Spatial modeling on the nutrient retention of an estuary wetland. Ecological Modelling 167, 33-46.

Li Y.B., Wang X.L., Han X.R., Li K.Q., Zhao X.X., Shi X.Y., 2008. An ecosystem model of the phytoplankton competition in the East China Sea, as based on field experiments. Hydrobiologia 600, 283-296.

Lin H.J., Shao K.T., Jan R.Q., Hsieh H.L., Chen C.P., Hsieh L.Y., Hsiao Y.T., 2007. A trophic model for the Danshuei River Estuary, a hypoxic estuary in northern Taiwan. Marine Pollution Bulletin 54, 1789-1800.

Lin J., Xie L., Pietrafesa L.J., Xu H., Woods W., Mallin M.A., Durako M.J., 2008. Water quality responses to simulated flow and nutrient reductions in the Cape Fear River Estuary and adjacent coastal region, North Carolina. Ecological Modelling 212, 200-217.

Liu B., de Swart H.E., 2015. Impact of river discharge on phytoplankton bloom dynamics in eutrophic estuaries: A model study. Journal of Marine Systems 152, 64-74.

Liu H., Xu W.S., Kang H.X., Yin B.S., Yang D.Z., 2014. Numerical simulation of the nutrient limitation in the Yangtze River Estuary, in: Ma S., Jia L., Li X., Wang L., Zhou H., Sun X. (Eds.), Life system modeling and simulation, pp. 188-197. 
Liu W.C., Chan W.T., 2014. Assessing the influence of nutrient reduction on water quality using a three-dimensional model: case study in a tidal estuarine system. Environmental Monitoring and Assessment 186, 8807-8825.

Liu W.C., Chen W.B., Kimura N., 2009. Measurement of sediment oxygen demand to simulate dissolved oxygen distribution: Case study in the main Danshuei River Estuary. Environmental Engineering Science 26, 1701-1711.

Liu Y., Arhonditsis G.B., Stow C.A., Scavia D., 2011. Predicting the hypoxic volume in Chesapeake Bay with the Streeter-Phelps model: A Bayesian approach. Journal of the American Water Resources Association 47, 1348-1363.

Liu Y., Evans M., Scavia D., 2010. Gulf of Mexico hypoxia: exploring increasing sensitivity to nitrogen loads. Environmental Science \& Technology 44, 5836-5841.

Liu Y., Scavia D., 2010. Analysis of the Chesapeake Bay hypoxia regime shift: insights from two simple mechanistic models. Estuaries and Coasts 33, 629-639.

Lonin S., Tuchkovenko Y., 2001. Water quality modelling for the ecosystem of the Cienaga de Tesca coastal lagoon. Ecological Modelling 144, 279-293.

Lopes J.F., Vaz N., Vaz L., Ferreira J.A., Dias J.M., 2015. Assessing the state of the lower level of the trophic web of a temperate lagoon, in situations of light or nutrient stress: A modeling study. Ecological Modelling 313, 59-76.

Los F.J., Blaas M., 2010. Complexity, accuracy and practical applicability of different biogeochemical model versions. Journal of Marine Systems 81(1-2), 44-74.

Los F.J., Troost T.A., van Beek, J.K.L., 2014. Finding the optimal reduction to meet all targets-Applying linear programming with a nutrient tracer model of the North Sea. Journal of Marine Systems 131, 91-101. 
Lovato T., Ciavatta S., Brigolin D., Rubino A., Pastres R., 2013. Modelling dissolved oxygen and benthic algae dynamics in a coastal ecosystem by exploiting real-time monitoring data. Estuarine Coastal and Shelf Science 119, 17-30.

Lowery T.A., 1998. Modelling estuarine eutrophication in the context of hypoxia, nitrogen loadings, stratification and nutrient ratios. Journal of Environmental Management 52, 289305.

Luang A.D., De Laender F., Olsen Y., Vadstein O., Dewulf J., Janssen C.R., 2014. Inferring time-variable effects of nutrient enrichment on marine ecosystems using inverse modelling and ecological network analysis. Science of the Total Environment 493, 708-718.

Lung W.S., 1988. The role of estuarine modeling in nutrient control. Water Science and Technology 20, 243-252.

Lung W.S., Nice A.J., 2007. Eutrophication model for the Patuxent Estuary: Advances in predictive capabilities. Journal of Environmental Engineering-Asce 133, 917-930.

Lung W.S., Testerman N., 1989. Modeling fate and transport of nutrients in the James Estuary. Journal of Environmental Engineering-Asce 115, 978-991.

Maar M., Timmermann K., Petersen J.K., Gustafsson K.E., Storm L.M., 2010. A model study of the regulation of blue mussels by nutrient loadings and water column stability in a shallow estuary, the Limfjorden. Journal of Sea Research 64, 322-333.

Machado D.A., Imberger J., 2014. Modeling the impact of natural and anthropogenic nutrient sources on phytoplankton dynamics in a shallow coastal domain, Western Australia. Environmental Fluid Mechanics 14, 87-111.

Madden C.J., Kemp W.M., 1996. Ecosystem model of an estuarine submersed plant community: calibration and simulation of eutrophication responses. Estuaries 19, 457-474. 
Magalhaes J., Flindt M.R., Marques J.C., Pardal M.A., 2008. Modelling nutrient mass balance in a temperate meso-tidal estuary: implications for management. Estuarine Coastal and Shelf Science 76, 175-185.

Malhadas M.S., Mateus M.D., Brito D., Neves R., 2014. Trophic state evaluation after urban loads diversion in a eutrophic coastal lagoon (Óbidos Lagoon, Portugal): a modeling approach. Hydrobiologia 740, 231-251.

Martins I., Marcotegui A., Marques J.C., 2008. Impacts of macroalgal spores on the dynamics of adult macroalgae in a eutrophic estuary: high versus low hydrodynamic seasons and longterm simulations for global warming scenarios. Marine Pollution Bulletin 56, 984-998. Martins I., Marques J.C., 2002. A model for the growth of opportunistic macroalgae (Enteromorpha sp.) in tidal estuaries. Estuarine Coastal and Shelf Science 55, 247-257. Martins I., Marques J.C., Jorgensen S.E., Nielsen S.N., 1997. Modelling the effects of green macroalgae blooms on the population dynamics of Cyathura carinata (Crustacea : Isopoda) in an eutrophied estuary. Ecological Modelling 102, 33-53.

Mathews A.L., Phlips E.J., Badylak S., 2015. Modeling phytoplankton productivity in a shallow, microtidal, subtropical estuary. Marine Ecology Progress Series 531, 63-80.

McEwan J., Gabric A.J., Bell P.R.F., 1998. Water quality and phytoplankton dynamics in Moreton Bay, south-eastern Queensland. II. Mathematical modelling. Marine and Freshwater Research 49, 227-239.

Meeuwig J.J., 1999. Predicting coastal eutrophication from land-use: an empirical approach to small non-stratified estuaries. Marine Ecology Progress Series 176, 231-241.

Meeuwig J.J., Kauppila P., Pitkanen H., 2000. Predicting coastal eutrophication in the Baltic: a limnological approach. Canadian Journal of Fisheries and Aquatic Sciences 57, 844-855. 
Meier H.E.M., Andersson H.C., Eilola K., Gustafsson B.G., Kuznetsov I., Muller-Karulis B., Neumann T., Savchuk O.P., 2011. Hypoxia in future climates: A model ensemble study for the Baltic Sea. Geophysical Research Letters 38.

Meier H.E.M., Hordoir R., Andersson H.C., Dieterich C., Eilola K., Gustafsson B.G., Hoglund A., Schimanke S., 2012. Modeling the combined impact of changing climate and changing nutrient loads on the Baltic Sea environment in an ensemble of transient simulations for 1961-2099. Climate Dynamics 39, 2421-2441.

Melesse A.M., Krishnaswamy J., Zhang, K.Q., 2008. Modeling coastal eutrophication at Florida bay using neural networks. Journal of Coastal Research 24, 190-196.

Ménesguen A., 1992. Modelling coastal eutrophication: the case of French Ulva blooms. Science of the Total Environment, pp. 979-992.

Ménesguen A., Cugier P., Leblond I., 2006. A new numerical technique for tracking chemical species in a multisource, coastal ecosystem applied to nitrogen causing Ulva blooms in the Bay of Brest (France). Limnology and Oceanography 51, 591-601.

Ménesguen A., Desmit X., Dulière V., Lacroix G., Thouvenin B., Thieu V., Dussauze M., 2018. How to avoid eutrophication in coastal seas? A new approach to derive river-specific combined nitrate and phosphate maximum concentrations. Science of the Total Environment, $628-629,400-414$.

Ménesguen A., Salomon J.-C., 1988. Eutrophication modelling as a tool for fighting against Ulva coastal mass blooms, Schrefler \& Zienkiewicz ed. Balkema, Rotterdam, pp. 443-450.

Miguez B.M., Farina-Busto L., Figueiras F.G., Perez F.F., 2001. Succession of phytoplankton assemblages in relation to estuarine hydrodynamics in the Ria de Vigo: a box model approach. Scientia Marina 65, 65-76.

Millie D.F., Weckman G.R., Paerl H.W., Pinckney J.L., Bendis B.J., Pigg R.J., Fahnenstiel G.L., 2006. Neural net modeling of estuarine indicators: Hindcasting phytoplankton biomass 
and net ecosystem production in the Neuse (North Carolina) and Trout (Florida) Rivers, USA. Ecological Indicators 6, 589-608.

Morse J., Eldridge P., 2007. A non-steady state diagenetic model for changes in sediment biogeochemistry in response to seasonally hypoxic/anoxic conditions in the "dead zone" of the Louisiana shelf. Marine Chemistry 106, 239-255.

Mukai T., Takimoto K., Shibata T., Abe H., 1985. Simulation study of eutrophication in Hiroshima bay - Simulation of particulate and dissolved organic matter using cyclic transformation of carbon. Water Research 19, 511-525.

Muller A.C., Muller D.L., 2015. Forecasting future estuarine hypoxia using a wavelet based neural network model. Ocean Modelling 96, 314-323.

Murray A.G., Parslow J.S., 1999. Modelling of nutrient impacts in Port Phillip Bay - a semienclosed marine Australian ecosystem. Marine and Freshwater Research 50, 597-611.

Muylaert K., Tackx M., Vyverman W., 2005. Phytoplankton growth rates in the freshwater tidal reaches of the Schelde estuary (Belgium) estimated using a simple light-limited primary production model. Hydrobiologia 540, 127-140.

Nash S., Hartnett M., Dabrowski T., 2011. Modelling phytoplankton dynamics in a complex estuarine system. Proceedings of the Institution of Civil Engineers-Water Management 164, $35-54$.

Neumann T., Fennel W., Kremp C., 2002. Experimental simulations with an ecosystem model of the Baltic Sea: A nutrient load reduction experiment. Global Biogeochemical Cycles 16.

Neumann T., Schernewski G., 2005. An ecological model evaluation of two nutrient abatement strategies for the Baltic Sea. Journal of Marine Systems 56, 195-206.

Neumann T., Schernewski G., 2008. Eutrophication in the Baltic Sea and shifts in nitrogen fixation analyzed with a 3D ecosystem model. Journal of Marine Systems 74, 592-602. 
Nielsen S., 1997. Examination and optimization of different exergy forms in macrophyte societies. Ecological Modelling 102, 115-127.

Nixon S.W., 2009. Eutrophication and the macroscope. Hydrobiologia. 629(1), 5-19.

Nobre A.M., Ferreira J.G., Newton A., Simas T., Icely J.D., Neves R., 2005. Management of coastal eutrophication: Integration of field data, ecosystem-scale simulations and screening models. Journal of Marine Systems 56, 375-390.

O'Boyle S., Wilkes R., McDermott G., Longphuirt S.N., Murray C., 2015. Factors affecting the accumulation of phytoplankton biomass in Irish estuaries and nearshore coastal waters: A conceptual model. Estuarine Coastal and Shelf Science 155, 75-88.

Obenour D., Michalak A., Scavia D., 2015. Assessing biophysical controls on Gulf of Mexico hypoxia through probabilistic modeling. Ecological Applications 25, 492-505.

Oguz T., Ducklow H., Malanotte-Rizzoli P., 2000. Modeling distinct vertical biogeochemical structure of the Black Sea: Dynamical coupling of the oxic, suboxic, and anoxic layers. Global Biogeochemical Cycles 14, 1331-1352.

Olufeagba B.J., Flake R.H., 1981. Modeling and control of dissolved oxygen in an estuary. Ecological Modelling 14, 79-94.

Onandia G., Gudimov A., Miracle M.R., Arhonditsis G., 2015. Towards the development of a biogeochemical model for addressing the eutrophication problems in the shallow hypertrophic lagoon of Albufera de Valencia, Spain. Ecological Informatics 26, 70-89.

OSPAR 1997. OSPAR Agreement 1997-17, The Common Procedure for the Identification of the Eutrophication Status of the OSPAR Maritime Area.

Padedda B.M., Luglie A., Ceccherelli G., Trebini F., Sechi N., 2010. Nutrient-flux evaluation by the LOICZ Biogeochemical Model in Mediterranean lagoons: the case of Cabras Lagoon (Central-Western Sardinia). Chemistry and Ecology 26, 147-162. 
Park K., Jung H.S., Kim H.S., Ahn S.M., 2005. Three-dimensional hydrodynamiceutrophication model (HEM-3D): application to Kwang-Yang Bay, Korea. Marine Environmental Research 60, 171-193.

Passy P., Gypens N., Billen G., Garnier J., Thieu V., Rousseau V., Callens J., Parent J.Y., Lancelot C., 2013. A-model reconstruction of riverine nutrient fluxes and eutrophication in the Belgian Coastal Zone since 1984. Journal of Marine Systems 128, 106-122.

Passy P., Le Gendre R., Garnier J., Cugier P., Callens J., Paris F., Billen G., Riou P., Romero E., 2016. Eutrophication modelling chain for improved management strategies to prevent algal blooms in the Bay of Seine. Marine Ecology Progress Series 543, 107-125.

Patricio J., Marques J.C., 2006. Mass balanced models of the food web in three areas along a gradient of eutrophication symptoms in the south arm of the Mondego estuary (Portugal). Ecological Modelling 197, 21-34.

Pätsch J., Radach G., 1997. Long-term simulation of the eutrophication of the North Sea: temporal development of nutrients, chlorophyll and primary production in comparison to observations. Journal of Sea Research 38, 275-310.

Pena M., Katsev S., Oguz T., Gilbert D., 2010. Modeling dissolved oxygen dynamics and hypoxia. Biogeosciences 7, 933-957.

Pénard C., Ménesguen A., Dumas F., Guillaud J.F., 2007. Towards operational modelling of the fate of nutrients in the coastal zone off Brittany (France). Houille Blanche-Revue Internationale De L Eau, 62-67.

Perrot T., Rossi N., Ménesguen A., Dumas F., 2014. Modelling green macroalgal blooms on the coasts of Brittany, France to enhance water quality management. Journal of Marine Systems 132, 38-53.

Peterson D.H., Festa J.F., 1984. Numerical simulation of phytoplankton productivity in partially mixed estuaries. Estuarine Coastal and Shelf Science 19, 563-589. 
Petihakis G., Triantafyllou G., Koutsoubas D., Allen I., Dounas C., 1999. Modelling the annual cycles of nutrients and phytoplankton in a Mediterranean lagoon (Gialova, Greece). Marine Environmental Research 48, 37-58.

Picart S.S., Allen J.I., Butenschon M., Artioli Y., de Mora L., Wakelin S., Holt J., 2015. What can ecosystem models tell us about the risk of eutrophication in the North Sea? Climatic Change 132, 111-125.

Plus M., Chapelle A., Lazure P., Auby I., Levavasseur G., Verlaque M., Belsher T., DeslousPaoli J.M., Zaldivar J.M., Murray C.N., 2003. Modelling of oxygen and nitrogen cycling as a function of macrophyte community in the Thau lagoon. Continental Shelf Research 23, 18771898.

Plus M., La Jeunesse I., Bouraoui F., Zaldivar J., Chapelle A., Lazure P., 2006. Modelling water discharges and nitrogen inputs into a Mediterranean lagoon - Impact on the primary production. Ecological Modelling 193, 69-89.

Powley H.R., Krom M.D., Emeis K.C., van Cappellen P., 2014. A biogeochemical model for phosphorus and nitrogen cycling in the Eastern Mediterranean Sea Part 2. Response of nutrient cycles and primary production to anthropogenic forcing: 1950-2000. Journal of Marine Systems 139, 420-432.

Qiao X.D., Wang B.D., Sun X., Liang S.K., 2014. Numerical simulation of nutrient and phytoplankton dynamics in Guangxi coastal bays, China. Journal of Ocean University of China 13, 338-346.

Rasmussen E.K., Petersen O.S., Thompson J.R., Flower R.J., Ayache F., Kraiem M., Chouba L., 2009. Model analyses of the future water quality of the eutrophicated Ghar El Melh lagoon (Northern Tunisia). Hydrobiologia 622, 173-193. 
Ren J.S., Barr N.G., Scheuer K., Schiel D.R., Zeldis J., 2014. A dynamic growth model of macroalgae: Application in an estuary recovering from treated wastewater and earthquakedriven eutrophication. Estuarine Coastal and Shelf Science 148, 59-69.

Robson B.J., Bukaveckas P.A., Hamilton D.P., 2008. Modelling and mass balance assessments of nutrient retention in a seasonally-flowing estuary (Swan River Estuary, Western Australia). Estuarine Coastal and Shelf Science 76, 282-292.

Roelke D.L., Eldridge P.M., Cifuentes L.A., 1999. A model of phytoplankton competition for limiting and nonlimiting nutrients: Implications for development of estuarine and nearshore management schemes. Estuaries 22, 92-104.

Rosenberg R., Olsson I., Olundh E., 1977. Energy-flow model of an oxygen-deficient estuary on Swedish West coast. Marine Biology 42, 99-107.

Rubegni F., Franchi E., Lenzi M., 2013. Relationship between wind and seagrass meadows in a non-tidal eutrophic lagoon studied by a Wave Exposure Model (WEMo). Marine Pollution Bulletin 70, 54-63.

Ruoho-Airola T., Eilola K., Savchuk O.P., Parviainen M., Tarvainen V., 2012. Atmospheric nutrient input to the Baltic Sea from 1850 to 2006: A reconstruction from modeling results and historical data. Ambio 41, 549-557.

Ryabchenko V.A., Karlin L.N., Isaev A.V., Vankevich R.E., Eremina T.R., Molchanov M.S., Savchuk O.P., 2016. Model estimates of the eutrophication of the Baltic Sea in the contemporary and future climate. Oceanology 56, 36-45.

Saraiva S., Pina P., Martins F., Santos M., Braunschweig F., Neves R., 2007. Modelling the influence of nutrient loads on Portuguese estuaries. Hydrobiologia 587, 5-18.

Savchuk O., Wulff F., 1999. Modelling regional and large-scale response of Baltic Sea ecosystems to nutrient load reductions. Hydrobiologia 393, 35-43. 
Savchuk O.P., Volkova V.V., 1990. Study and forecast of Baltic Sea eutrophication with the help of simulation model. Doklady Akademii Nauk Sssr 314, 1006-1009.

Savchuk O.P., Wulff F., 2007. Modeling the Baltic Sea eutrophication in a decision support system. Ambio 36, 141-148.

Savchuk O.P., Wulff F., 2009. Long-term modeling of large-scale nutrient cycles in the entire Baltic Sea. Hydrobiologia 629, 209-224.

Scavia D., Donnelly K., 2007. Reassessing hypoxia forecasts for the Gulf of Mexico. Environmental Science \& Technology 41, 8111-8117.

Scavia D., Rabalais N., Turner R., Justic D., Wiseman W., 2003. Predicting the response of Gulf of Mexico hypoxia to variations in Mississippi River nitrogen load. Limnology and Oceanography 48, 951-956.

Schernewski G., Wielgat M., 2001. Eutrophication of the shallow Szczecin Lagoon (Baltic Sea): modelling, management and the impact of weather, in: Brebbia C.A. (Ed.), Coastal Engineering V: Computer Modelling of Seas and Coastal Regions, pp. 87-98.

Shen J., 2006. Optimal estimation of parameters for a estuarine eutrophication model. Ecological Modelling 191, 521-537.

Shen J., Kuo A.Y., 1996. Inverse estimation of parameters for an estuarine eutrophication model. Journal of Environmental Engineering-Asce 122, 1031-1040.

Shen J., Kuo A.Y., 1998. Application of inverse method to calibrate estuarine eutrophication model. Journal of Environmental Engineering-Asce 124, 409-418.

Shepherd D., Burgess D., Jickells T., Andrews J., Cave R., Turner R.K., Aldridge J., Parker E.R., Young E., 2007. Modelling the effects and economics of managed realignment on the cycling and storage of nutrients, carbon and sediments in the Blackwater Estuary, UK. Estuarine Coastal and Shelf Science 73, 355-367. 
Silva-Santos P., Pardal M.K., Lopes R.J., Murias T., Cabral J.A., 2006. A stochastic dynamic methodology (SDM) to the modelling of trophic interactionsl with a focus on estuarine eutrophication scenarios. Ecological Indicators 6, 394-408.

Skerratt J., Wild-Allen K., Rizwi F., Whitehead J., Coughanowr C., 2013. Use of a high resolution 3D fully coupled hydrodynamic, sediment and biogeochemical model to understand estuarine nutrient dynamics under various water quality scenarios. Ocean \& Coastal Management 83, 52-66.

Skogen M., Mathisen L., 2009. Long-term effects of reduced nutrient inputs to the North Sea. Estuarine Coastal and Shelf Science 82, 433-442.

Skogen M.D., Eilola K., Hansen J.L.S., Meier H.E.M., Molchanov M.S., Ryabchenko V.A., 2014. Eutrophication status of the North Sea, Skagerrak, Kattegat and the Baltic Sea in present and future climates: A model study. Journal of Marine Systems 132, 174-184.

Slomp C., Epping E., Helder W., van Raaphorst W., 1996. A key role for iron-bound phosphorus in authigenic apatite formation in North Atlantic continental platform sediments. Journal of Marine Research 54, 1179-1205.

Smith S.V., Hollibaugh J.T., 1989. Carbon-controlled nitrogen cycling in a marine macrocosm - An ecosystem-scale model for managing cultural eutrophication. Marine Ecology Progress Series 52, 103-109.

Soetaert K., Herman P.M.J., Kromkamp J., 1994. Living in the twilight - Estimating net phytoplankton growth in the Westerschelde estuary (The Netherlands) by means of an ecosystem model (MOSES). Journal of Plankton Research 16, 1277-1301.

Soetaert K., Middelburg J.J., 2009. Modeling eutrophication and oligotrophication of shallowwater marine systems: the importance of sediments under stratified and well-mixed conditions. Hydrobiologia 629, 239-254. 
Sohma A., Sekiguchi Y., Kuwae T., Nakamura Y., 2008. A benthic-pelagic coupled ecosystem model to estimate the hypoxic estuary including tidal flat - Model description and validation of seasonal/daily dynamics. Ecological Modelling 215, 10-39.

Sohma A., Sekiguchi Y., Nakata K., 2004. Modeling and evaluating the ecosystem of seagrass beds, shallow waters without sea-grass, and an oxygen-depleted offshore area. Journal of Marine Systems 45, 105-142.

Solidoro C., Brando V., Dejak C., Franco D., Pastres R., Pecenik G., 1997a. Long term simulations of population dynamics of Ulva rigida in the lagoon of Venice. Ecological Modelling 102, 259-272.

Solidoro C., Dejak C., Franco D., Pastres R., Pecenik G., 1995. A model for macroalgae and phytoplankton growth in the Venice lagoon. Environment International 21, 619-626.

Solidoro C., Pecenik G., Pastres R., Franco D., Dejak C., 1997b. Modelling macroalgae (Ulva rigida) in the Venice lagoon: Model structure identification and first parameters estimation. Ecological Modelling 94, 191-206.

Spatharis S., Tsirtsis G., 2013. Zipf-Mandelbrot model behavior in marine eutrophication: two way fitting on field and simulated phytoplankton assemblages. Hydrobiologia 714, 191-199.

Steward J.S., Lowe E.F., 2010. General empirical models for estimating nutrient load limits for Florida's estuaries and inland waters. Limnology and Oceanography 55, 433-445.

Stow C.A., Scavia D., 2009. Modeling hypoxia in the Chesapeake Bay: Ensemble estimation using a Bayesian hierarchical model. Journal of Marine Systems 76, 244-250.

Sturdivant S.K., Brush M.J., Diaz R.J., 2013. Modeling the effect of hypoxia on macrobenthos production in the lower Rappahannock River, Chesapeake Bay, USA. Plos One 8. 
Sugimoto R., Kasai A., Miyajima T., Fujita K., 2010. Modeling phytoplankton production in Ise Bay, Japan: Use of nitrogen isotopes to identify dissolved inorganic nitrogen sources. Estuarine Coastal and Shelf Science 86, 450-466.

Sundarambal P., Tkalich P., Balasubramanian R., 2010. Modelling the effect of atmospheric nitrogen deposition on marine phytoplankton in the Singapore Strait. Water Science and Technology 61, 859-867.

Talke S.A., de Swart H.E., de Jonge V.N., 2009. An idealized model and systematic process study of oxygen depletion in highly turbid estuaries. Estuaries and Coasts 32, 602-620.

Tamvakis A., Miritzis J., Tsirtsis G., Spyropoulou A., Spatharis S., 2012. Effects of meteorological forcing on coastal eutrophication: Modeling with model trees. Estuarine Coastal and Shelf Science 115, 210-217.

Testa J.M., Li Y., Lee Y.J., Li M., Brady D.C., Di Toro D.M., Kemp W.M., Fitzpatrick J.J., 2014. Quantifying the effects of nutrient loading on dissolved $\mathrm{O}_{2}$ cycling and hypoxia in Chesapeake Bay using a coupled hydrodynamic-biogeochemical model. Journal of Marine Systems 139, 139-158.

Tett P., Walne A., 1995. Observations and simulations of hydrography, nutrients and plankton in the Southern North Sea. Ophelia 42, 371-416.

Timmermann K., Dinesen G.E., Markager S., Ravn-Jonsen L., Bassompierre M., Roth E., Stottrup J.G., 2014. Development and use of a bioeconomic model for management of mussel fisheries under different nutrient regimes in the temperate estuary of the Limfjord, Denmark. Ecology and Society 19.

Timmermann K., Markager S., Gustafsson K.E., 2010. Streams or open sea? Tracing sources and effects of nutrient loadings in a shallow estuary with a 3D hydrodynamic-ecological model. Journal of Marine Systems 82, 111-121. 
Townsend H., 2014. Comparing and coupling a water quality and a fisheries ecosystem model of the Chesapeake Bay for the exploratory assessment of resource management strategies. Ices Journal of Marine Science 71, 703-712.

Trancoso A.R., Saraiva S., Fernandes L., Pina P., Leitao P., Neves R., 2005. Modelling macroalgae using a 3D hydrodynamic-ecological model in a shallow, temperate estuary. Ecological Modelling 187, 232-246.

Troost T.A., Blaas M., Los F.J., 2013. The role of atmospheric deposition in the eutrophication of the North Sea: A model analysis. Journal of Marine Systems 125, 101-112. Troost T.A., de Kluijver A., Los F.J., 2014. Evaluation of eutrophication variables and thresholds in the Dutch North Sea in a historical context - A model analysis. Journal of Marine Systems 134, 45-56.

Tuchkovenko Y.S., Lonin S.A., 2003. Mathematical model of the oxygen regime of Cartagena Bay. Ecological Modelling 165, 91-106.

Turner E., Bruesewitz D., Mooney R., Montagna P., McClelland J., Sadovski A., Buskey E., 2014. Comparing performance of five nutrient phytoplankton zooplankton (NPZ) models in coastal lagoons. Ecological Modelling 277, 13-26.

Turner R., Rabalais N., Swenson E., Kasprzak M., Romaire T., 2005. Summer hypoxia in the northern Gulf of Mexico and its prediction from 1978 to 1995. Marine Environmental Research 59, 65-77.

van den Berg A.J., Ridderinkhof H., Riegman R., Ruardij P., Lenhart H., 1996a. Influence of variability in water transport on phytoplankton biomass and composition in the southern North Sea: A modelling approach (FYFY). Continental Shelf Research 16(7), 907-931. van den Berg A.J., Turner S.M., vanDuyl F.C., Ruardij P., 1996b. Model structure and analysis of dimethylsulphide (DMS) production in the southern North Sea, considering 
phytoplankton dimethylsulphoniopropionate- (DMSP) lyase and eutrophication effects. Marine Ecology Progress Series 145, 233-244.

Vanderborght J.P., Wollast R., Loijens M., Régnier P., 2002. Application of a transportreaction model to the estimation of biogas fluxes in the Scheldt estuary. Biogeochemistry. 59(1-2), 207-237.

van Raaphorst W., Ruardij P., Brinkman A., 1988. The assessment of benthic phosphorus regeneration in an estuarine ecosystem model. Netherlands Journal of Sea Research 22, 2336.

Vollenweider R. A., 1968. Scientific fundamentals of the eutrophication of lakes and flowing waters, with particular reference to nitrogen and phosphorus as factors in eutrophication. Tech. Report. DAS/CSI/68.27, OECD, Paris, 150 pp + figures.

Wan Z., She J., Maar M., Jonasson L., Baasch-Larsen J., 2012. Assessment of a physicalbiogeochemical coupled model system for operational service in the Baltic Sea. Ocean Science 8, 683-701.

Wang C., Sun Q.Y., Wang P.F., Hou J., Qu A.Y., 2013. An optimization approach to runoff regulation for potential estuarine eutrophication control: Model development and a case study of Yangtze Estuary, China. Ecological Modelling 251, 199-210.

Wild-Allen K., Herzfeld M., Thompson P.A., Rosebrock U., Parslow J., Volkman J.K., 2010. Applied coastal biogeochemical modelling to quantify the environmental impact of fish farm nutrients and inform managers. Journal of Marine Systems 81, 134-147.

Wild-Allen K., Rayner M., 2014. Continuous nutrient observations capture fine-scale estuarine variability simulated by a 3D biogeochemical model. Marine Chemistry 167, 135149.

Yakushev E., Neretin L., 1997. One-dimensional modeling of nitrogen and sulfur cycles in the aphotic zones of the Black and Arabian Seas. Global Biogeochemical Cycles 11, 401-414. 
Yakushev E., Pollehne F., Jost G., Kuznetso I., Schneider B., Urnlauf L., 2007. Analysis of the water column oxic/anoxic interface in the Black and Baltic seas with a numerical model. Marine Chemistry 107, 388-410.

Yanagi T., Yamamoto T., Koizumi Y., Ikeda T., Kamizono M., Tamori H., 1995. A numerical simulation of red tide formation. Journal of Marine Systems 6, 269-285.

Yekta S.S., Rahm L., 2011. A model study of the effects of sulfide-oxidizing bacteria (Beggiatoa spp.) on phosphorus retention processes in hypoxic sediments: Implications for phosphorus management in the Baltic Sea. Boreal Environment Research 16, 167-184.

Zhang J.H., Liu C.C., Yang L.L., Gao S., Ji X., Huo Y.Z., Yu K.F., Xu R., He P.M., 2015. The source of the Ulva blooms in the East China Sea by the combination of morphological, molecular and numerical analysis. Estuarine Coastal and Shelf Science 164, 418-424.

Zouiten H., Diaz C.A., Gomez A.G., Cortezon J.A.R., Alba J.G., 2013. An advanced tool for eutrophication modeling in coastal lagoons: Application to the Victoria lagoon in the north of Spain. Ecological Modelling 265, 99-113. 


\section{Table captions}

Table 1. Statistics of the reference collecting process.

\begin{tabular}{|c|c|c|c|c|c|}
\hline & Search equation & $\begin{array}{l}\text { References } \\
\text { collected }\end{array}$ & $\begin{array}{l}\text { References } \\
\text { discarded }\end{array}$ & $\begin{array}{l}\text { References } \\
\text { added }\end{array}$ & $\begin{array}{l}\text { References } \\
\text { used }\end{array}$ \\
\hline Estuaries & $\begin{array}{l}\text { TITLE : (eutrophic* OR oxygen* } \\
\text { OR hypox* OR anox* OR } \\
\text { phytoplankton* OR "harmful } \\
\text { alga"* OR nutrient* OR } \\
\text { cyanobact* OR proliferat*) AND } \\
\text { (model* OR numerical OR } \\
\text { simulat* OR predict*) AND } \\
\text { estuar* }\end{array}$ & 129 & 51 & 5 & 83 \\
\hline Lagoons & $\begin{array}{l}\text { TITLE: (((eutrophic* OR oxygen* } \\
\text { OR hypox* OR anox* OR } \\
\text { phytoplankton* OR "harmful } \\
\text { alga"* OR nutrient* OR } \\
\text { cyanobact* OR proliferat*) AND } \\
(\text { model* OR numerical OR } \\
\text { simulat*) AND lagoon*)) }\end{array}$ & 38 & 13 & 5 & 30 \\
\hline Coastal seas & $\begin{array}{l}\text { TITLE: ((eutrophic* OR oxygen* } \\
\text { OR hypox* OR anox* OR } \\
\text { phytoplankton* OR "harmful } \\
\text { alga"* OR phaeocystis OR } \\
\text { nutrient* OR cyanobact* OR } \\
\text { proliferat*) AND (model* OR } \\
\text { numerical OR simulat* OR } \\
\text { predict*) AND (marine OR bay* } \\
\text { OR coastal OR sea)) } \\
\text { AND TOPIC: (eutrophic*) }\end{array}$ & 184 & 68 & 37 & 153 \\
\hline "Green tides" & $\begin{array}{l}\text { TITLE: ((( "green alga"* OR } \\
\text { "green tide*" OR macroalg* OR } \\
\text { ulva ) AND (model* OR numerical } \\
\text { OR simulat*))) } \\
\text { AND TOPIC: (eutrophic* OR } \\
\text { hypox* OR anox*) }\end{array}$ & 17 & 4 & 12 & 25 \\
\hline
\end{tabular}

Table 1 


\section{Figure captions}

Figure 1. Number of modelling studies of marine eutrophication over time.

Figure 2. World distribution of the models of marine eutrophication.

Figure 3. Diagrams illustrating various spatial approaches of a marine coastal water body with an estuary.

Figure 4. Cartesian vs curvilinear vs finite triangular element grids(sources: RBINS/Belgium, Deltares/The Netherlands, ISMAR-CNR/Italy)

Figure 5. $\sigma$-coordinate vs $\mathrm{z}$-coordinate in the vertical plane.

Figure 6. Taylor and Target diagrams. 


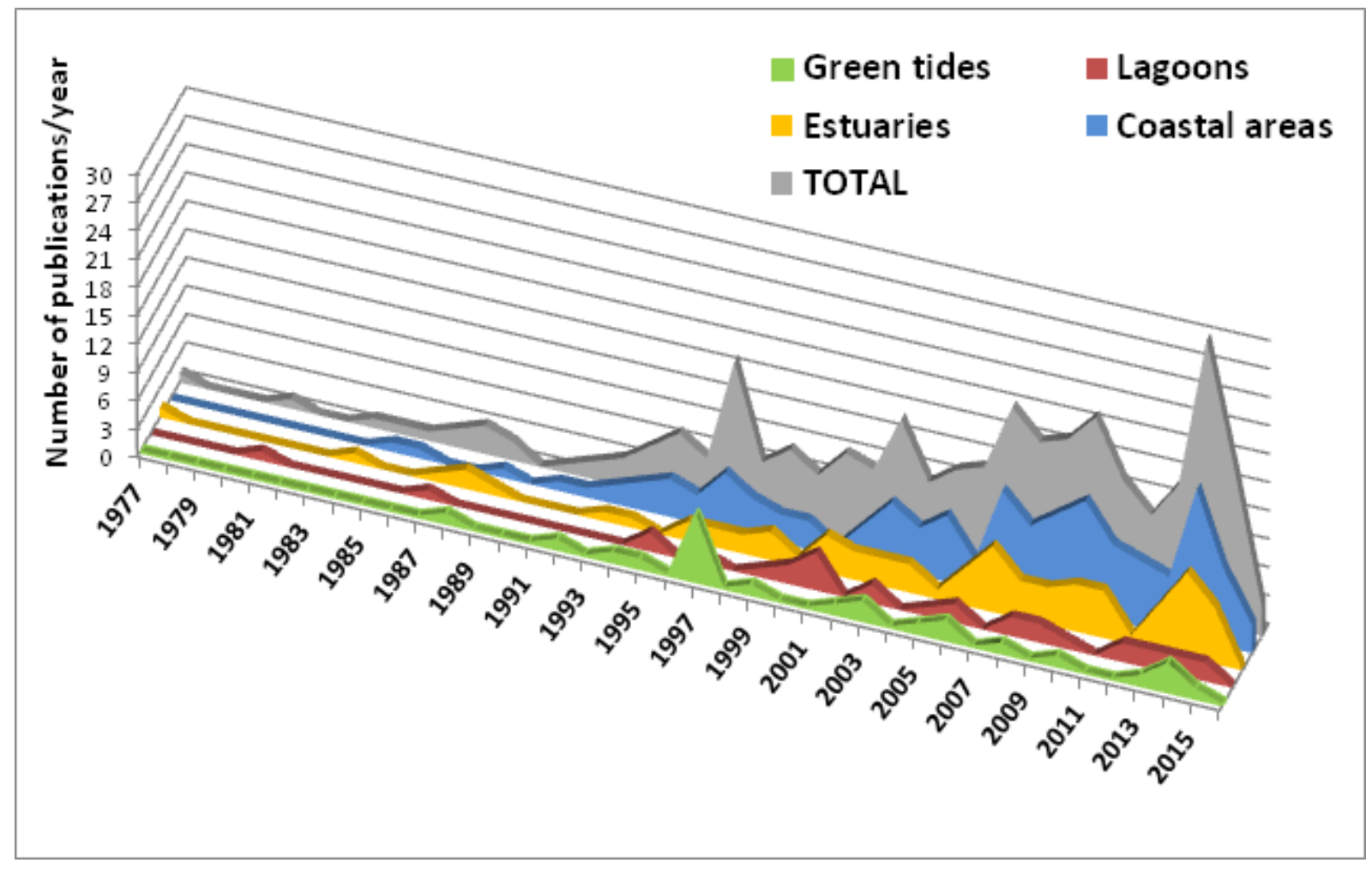

Figure 1 


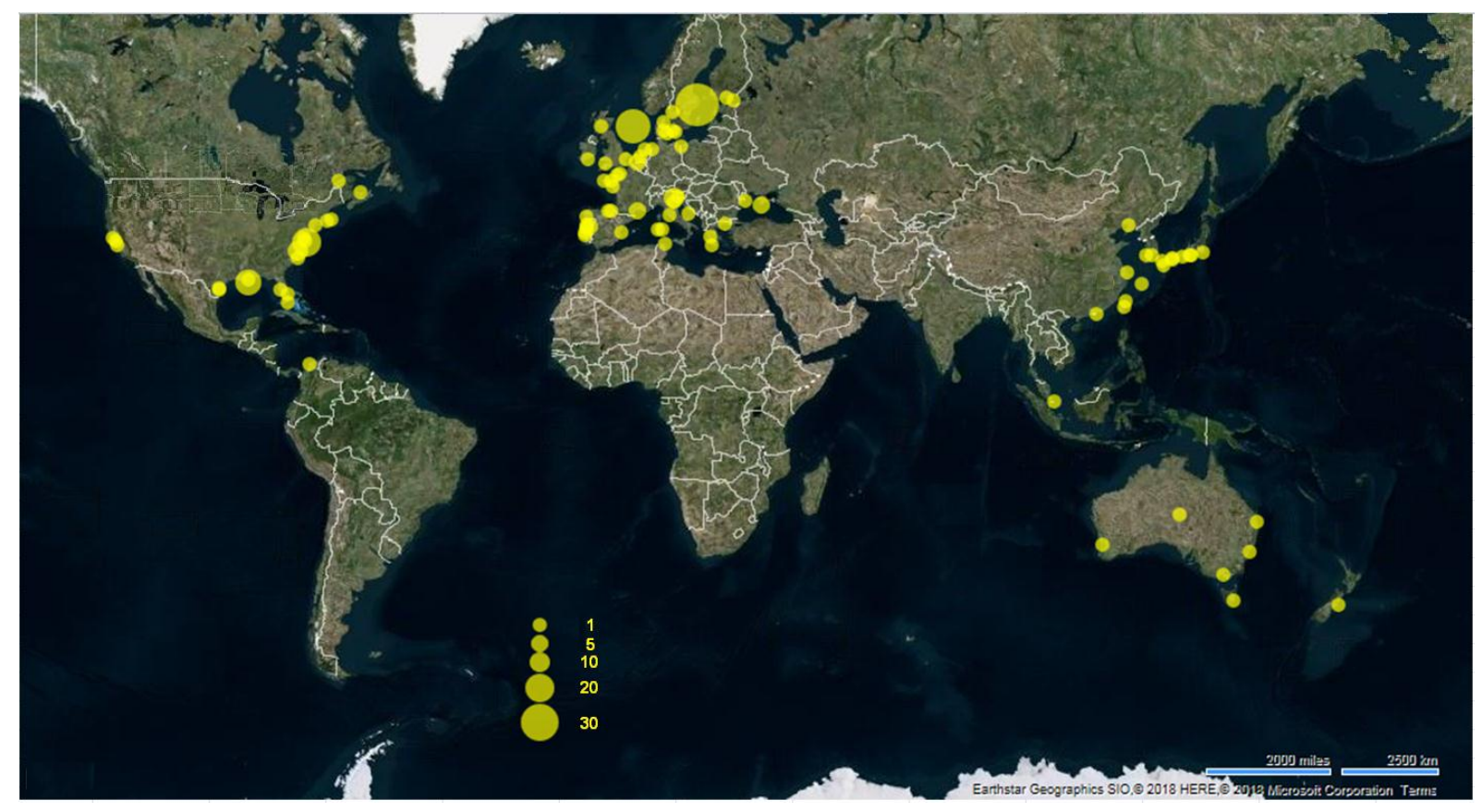

Figure 2 


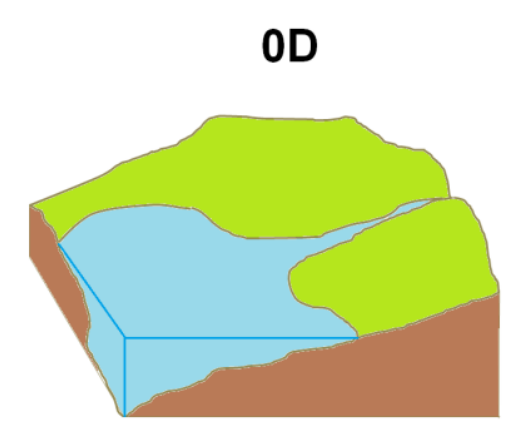

2DV

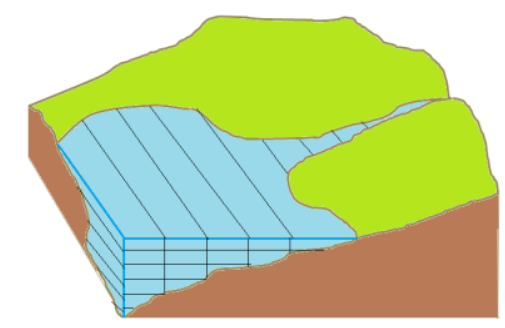

1DH

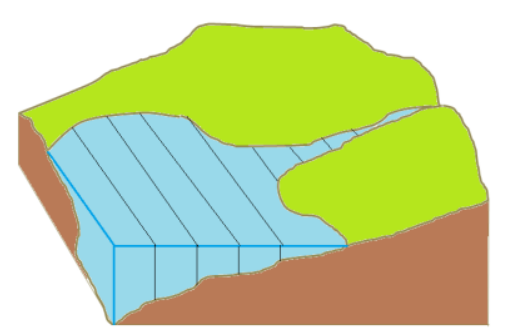

2DH

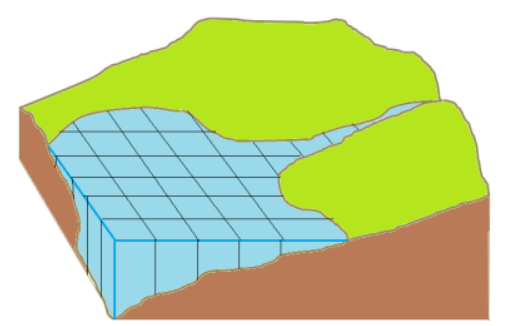

1DV

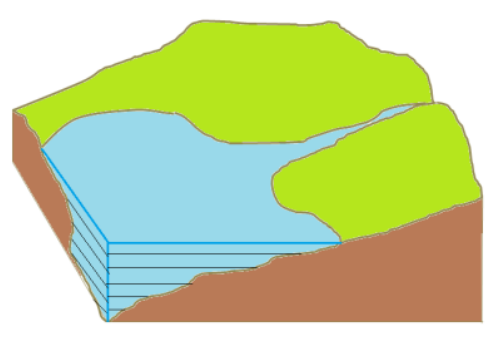

3D

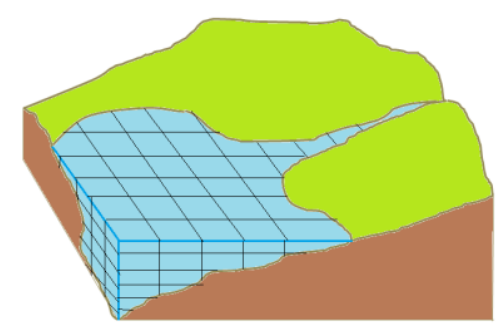

Figure 3 

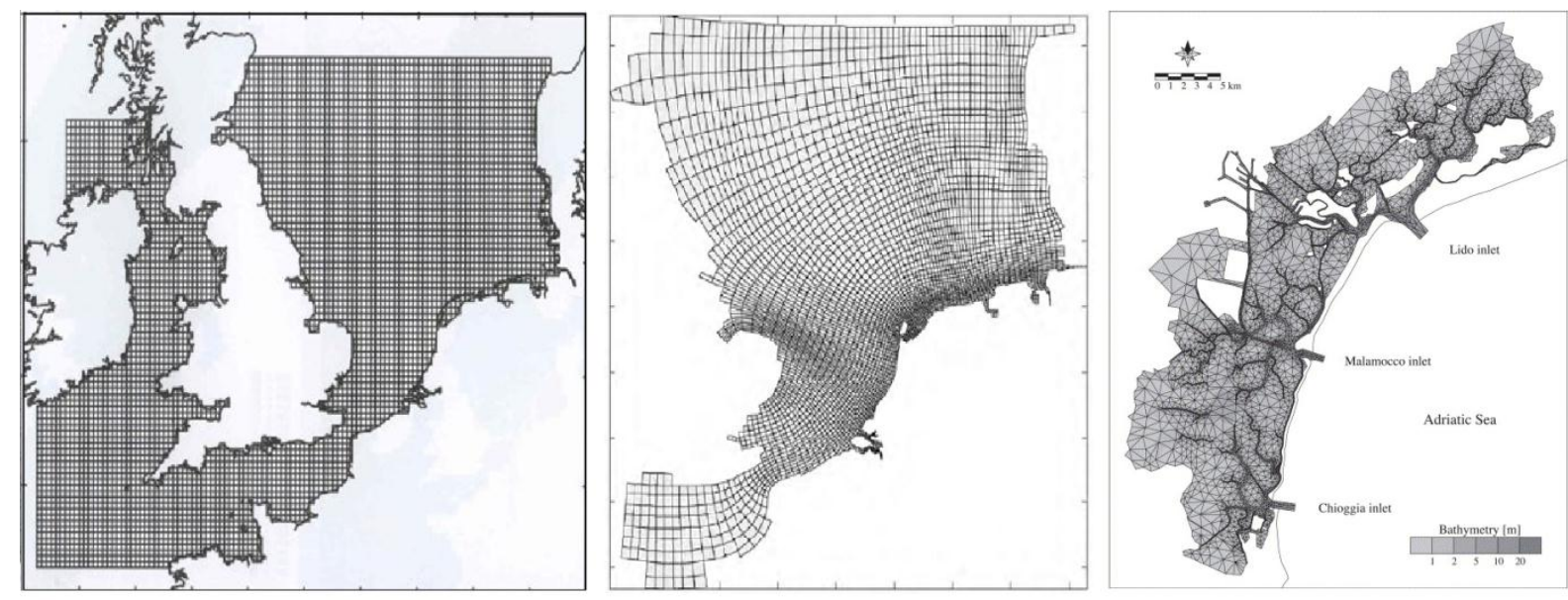

Figure 4 

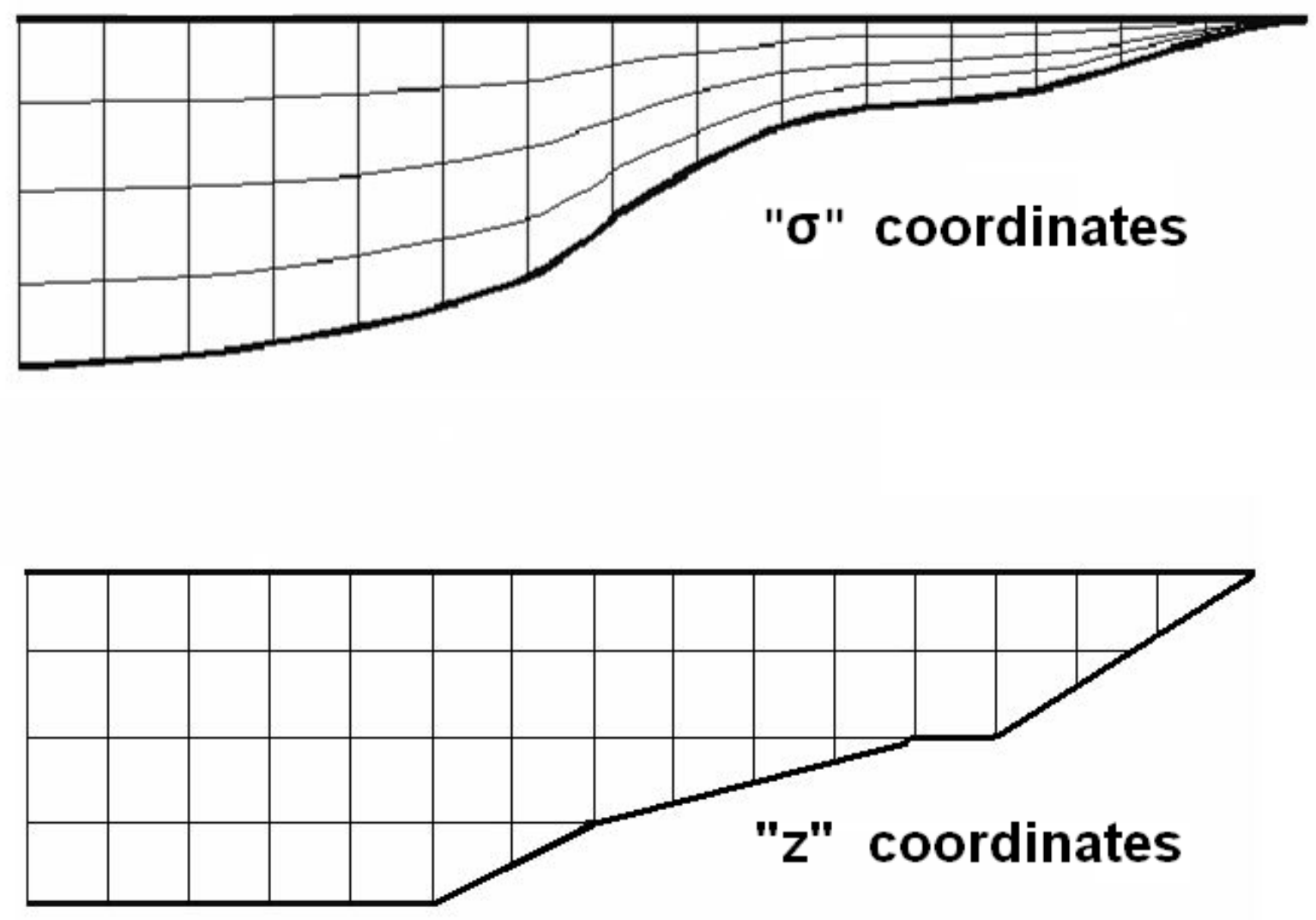

Figure 5 

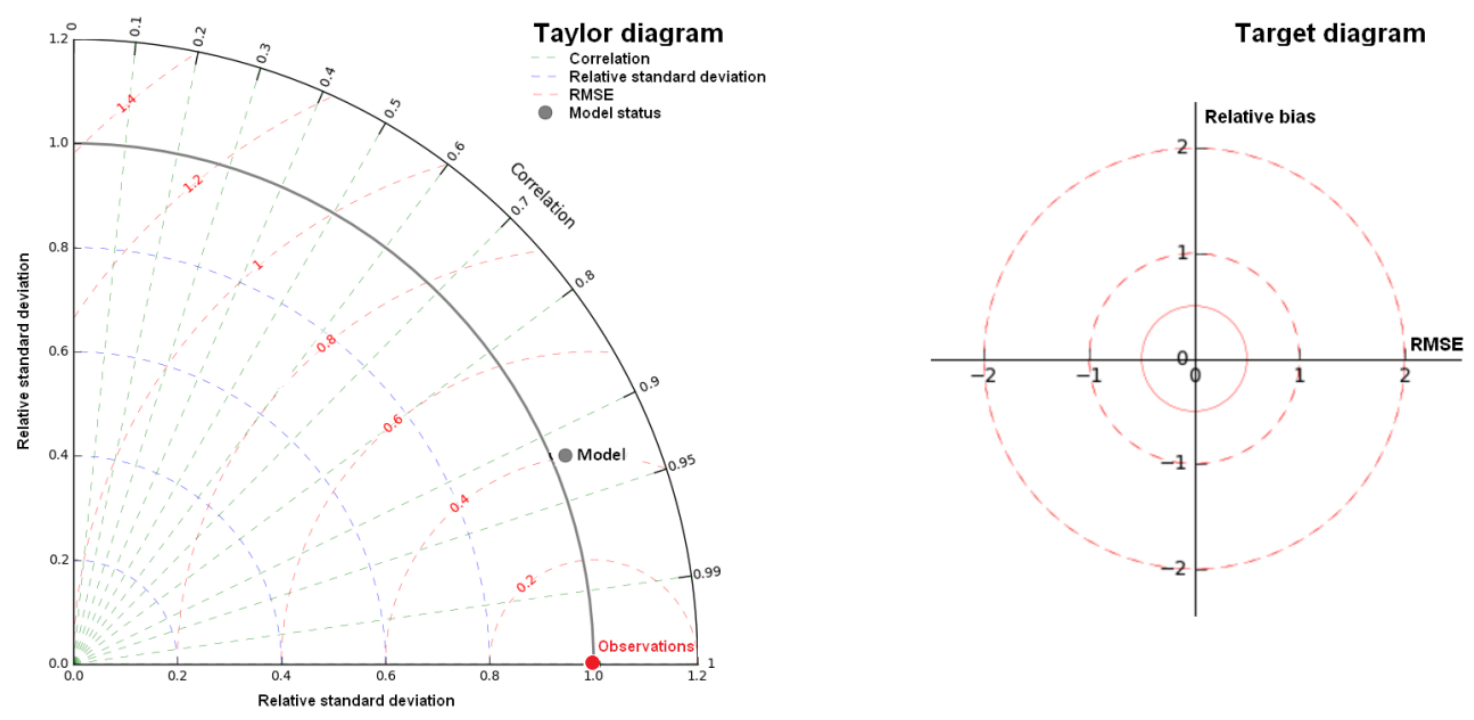

Figure 6 